\title{
Can Social Capital and Reputation Mitigate Political and Industry-wide Economic Risk?
}

\author{
Dimitris Andriosopoulos ${ }^{1, *}$, Sheikh Tanzila Deepty ${ }^{1}$ \\ ${ }^{1}$ University of Strathclyde, 199 Cathedral Street, Glasgow, G4 OQU, UK
}

15 January 2019

\begin{abstract}
Firms' social capital, captured by corporate social responsibility (CSR), can serve as an operational hedging instrument for firm-specific negative shocks. This paper assess CSR's hedging effectiveness against risks arising from political uncertainty and industry-wide economic shocks. We find that CSR has a significant mitigating effect on stock return volatility making it an effective reputational hedge against political risk such as gubernatorial elections, especially for closely contested elections. However, CSR's hedging is effective only for market risk (stock volatility) and not for cash flow volatility. Meanwhile, a difference-in-difference estimation suggests that CSR is not an effective hedge against risk during industry-wide economic shocks. Finally, CSR's mitigating effect on stock volatility is transient.
\end{abstract}

JEL classification: G18; G32; G38

Keywords: CSR, social capital, risk, gubernatorial elections, tariff shocks, operational hedge

*Corresponding author: email: d.andriosopoulos@ strath.ac.uk, tel: +44 (0) 1415483892. 
"CSR has moved from the periphery of business to center stage."

Unilever Chairman Niall Fitzgerald (2003).

\section{Introduction}

The focus on social capital as a significant link to ultimate success or failure has been on the rise over the past few years. For instance, a 2017 survey by Deloitte shows that $88 \%$ of millennials judge a firm on the basis of its social impact in addition to financial performance. Meanwhile, a 2018 Deloitte survey shows that $77 \%$ of global leaders consider a company's social impact track record and corporate citizenship to matter to stakeholders. Social capital also has significant tangible effects. During periods of unexpectedly low trust investors perceive firms with high social capital to be more trustworthy and place higher valuation premiums on these firms (Lins et al., 2017). However, enhancing social capital comes with the trade-off of reduced financial flexibility, especially at times of negative shocks when firms need to balance stakeholders' expectations and social capital against earnings targets (Becchetti et al., 2015). Therefore, high social capital firms have a reduced flexibility leading to their earnings being relatively less predictable, which increases firm risk. This paper addresses two questions. Can CSR mitigate the potential fallout of political and industry-wide adverse effects and uncertainty? Does the potential hedging effect of CSR last over the long-term?

From a firm's perspective, social capital defines the relationship quality that a firm and its executives build with their stakeholders (Servaes and Tamayo, 2017), whereas corporate social responsibility (CSR) is a core business strategy to build social capital (Antoni and Sacconi, 2011). Therefore, CSR activities can be a proxy for firms' social capital. ${ }^{1}$ For instance, evidence already exists suggesting that CSR affects firm value by reducing the cost of capital (Hasan et al., 2017) and improving cash flows (Gregory et al., 2014).

\footnotetext{
${ }^{1}$ Hereafter, we use the term "social capital" and "CSR" interchangeably.
} 
Based on the signaling theory, CSR investment reduces information asymmetries between firm and stakeholders by signaling firms' unobservable moral attributes (Rindova et al., 2005; Porter and Kramer, 2006) and build a good reputation (Fombrun and Shanley, 1990). Moreover, the trust that firms build with their stakeholders via CSR allows them to perform better during a financial crisis (Lins et al., 2017) and firm-specific negative shocks (e.g., Godfrey et al., 2009; Choi and Wang, 2009). In response to the CSR reputation the relevant stakeholders trust firms during firm-specific negative events (i.e., reputation effects in a repeated game). We argue that in order to understand the hedging ability of CSR, the focus should also be on regional or industry-wide uncertainty.

Based on the interaction between signaling theory and reputation effects in the repeated game, when there is an economy-wide or industry-wide adverse shock CSR reputation can be used as an operational hedge to protect a firm as is the case for firm-specific adverse events. Overall, it is reasonable to expect that CSR reputation has an inverse relation with firm risk during an economic or industry-wide crisis. By exploring the hedging ability of CSR we provide empirical evidence to firms' risk management initiatives which can benefit firm value during times of economic and industry-wide uncertainty. Therefore, we examine the hedging ability of CSR for two components of idiosyncratic volatility: stock return volatility and cash flow volatility. ${ }^{2}$

For empirical identification we use two exogenous shocks that affect firm risk. First, we use a gubernatorial election year as an economy-wide political risk. A strand of the literature argues that as incumbents have incentives to signal higher competency before the election in response to the myopic behavior of voters, political cycles arise in macroeconomic policies

\footnotetext{
${ }^{2}$ By decomposing the firm-level stock return variance, Campbell and Shiller (1988) and Vuolteenaho (2002) show that idiosyncratic volatility originates from cash flow shocks and expected return shocks.
} 
(Nordhaus, 1975; Rogoff, 1987). Subsequently, potential policy changes surrounding these cycles and electoral competitiveness create uncertainty in a business environment (Gulen and Ion, 2016; Baker et al., 2016; Julio and Yook, 2016). Political uncertainty augments the expected return volatility around an election as the stock return has exposure to systematic economic forces (Fama and French, 1988, 1989; Campbell, 1985; Chen, 1991; Bailey and Chung, 1995). The second exogenous shocks we use are significant reductions in industrylevel import tariffs which are exogenous macroeconomic shocks. Import tariff cuts intensify competitive pressure from foreign competitors for all domestic firms in the industry (Bernard et al., 2006). Therefore, a significant tariff cut creates industry-wide adverse cash flow shock (Kini et al., 2017).

We analyze all publicly listed U.S. firms, excluding financial and utilities firms, during 2002 to 2016. As gubernatorial elections occur in different states and at different times, they give us a powerful econometric test. In addition to time series variation, gubernatorial elections have a cross-sectional variation which strengthens our findings. Arguably, a reverse causality between CSR and risk can exist, since, firm risk can also affect its CSR engagement (Hong et al., 2012; Albuquerque et al., 2018). Since this reverse causality can potentially lead to biased results we use an instrumental variable (IV) approach to measure CSR-risk relation by instrumenting CSR with average CSR rating for each industry-year pair and state-year pair (excluding focal firm). Alternatively, we apply difference-in-difference methodology and use industry-level import tariff cuts as a quasi-natural experiment to isolate the causal effect of risk on CSR.

Our findings suggest that CSR reputation reduces stock return volatility during an election year. Moreover, the hedging-ability of CSR has a stronger impact during the uncertainty caused by closely contested elections compared to all other election years. Our findings suggest that shareholders value firm-specific social capital during periods of economic uncertainty driven 
by elections and this reliance increases with the degree of uncertainty. Our results are also economically significant. For instance, a one-standard-deviation increase in CSR score reduces the stock return volatility by $6.52 \%$ during a gubernatorial election and $10.96 \%$ during closely contested election for firms headquartered in states facing gubernatorial election. However, we do not find strong evidence that CSR reputation can mitigate cash flow volatility during political uncertainty. We argue that this is driven by the fact that firms increase cash holdings as a precautionary buffer during an election year (Julio and Yook, 2012) and because the uncertainty regarding future cash flows driven by the uncertainty of future political party orientation (Boutchkova et al., 2012). Therefore, there is a weak relation between CSR and cash flow volatility.

We also test whether CSR has a longer-term or transient hedging ability by assessing its impact on firm risk during the post-election period. Our results support the argument that the CSR reputation effect on firm risk is transient. Moreover, from a difference-in-difference empirical setting we find that just by having a CSR score has a mitigating effect on firms' stock return volatility during industry-wide economic shocks, such as import tariff cuts. However, we find that although CSR reduces stock return volatility and cash flow volatility, whether firms have a high or low CSR score has no impact on firm risk during times of industry-wide economic shocks. Overall, CSR is an effective reputational hedge against regional political risk (elections), but not so for industry-wide economic shocks (import tariff cuts). However, CSR's hedging ability is transient and does not persist during the years following the shock.

\section{Theoretical background and hypotheses development}

\subsection{Social Capital, CSR, and operational hedging}

In a broader sense, social capital is the productive value of social networks. Leana and Van Buren (1999) delineate social capital from an organizational perspective and define it as a resource that reveals the propensity of social relations between a firm and its stakeholders. 
However, it is challenging to measure social capital due to its broadly defined definitions. To address this challenge, we follow the view of some recent works (Degli Antoni and Sacconi, 2011; Lins et al., 2017) and consider CSR activities as a proxy for firms' social capital. CSR can generate social capital by building trust while it establishes cooperating networks between the company and its stakeholders. This feature of CSR directly conforms to 'civic engagement' and 'trust and cooperative norms' aspects of cognitive and structural theories of social capital. ${ }^{3}$ The concept of CSR has gradually shifted from macro-social effects to the organizational level effect (Idowu et al., 2010). In line with resource-based view (RBV) and instrumental stakeholder theory CSR creates firm value by generating competitive advantages (Branco and Rodrigues, 2006) in a number of ways. For instance via socially responsible human resource activities (Turban and Greening, 1997) and superior environmental performance (Russo and Fouts, 1997; Mcwilliams and Siegel, 2001).

Reputation is another channel of value creation, which also motivates firms to engage in CSR (Porter and Kramer, 2006). CSR investment reduces information asymmetries between firms and stakeholders (Fombrun and Shanley, 1990; Hur et al., 2014), and builds reputation by signaling unobservable firm attributes (such as quality, capability, honesty) (Rindova et al., 2005; Miller et al., 2009; Porter and Kramer, 2006). This CSR function complies with the basic concept of the signaling theory. Moreover, high-CSR firms signal the executives' competency and morality to stakeholders (Milbourn, 2003; Francis et al., 2008) and enhance managerial reputation (Borghesi et al., 2014; Dögl and Holtbrügge, 2014). ${ }^{4}$ CSR reputation accumulates

\footnotetext{
${ }^{3}$ Cognitive perspective refers to internal and subjective form of social capital, such as shared norms, values, attitudes, and beliefs (Putnam, 1999; Uphoff and Wijayaratna, 2000). Structural theory refers to the pattern and intensity of networks to create and maintain social relationships (Uphoff and Wijayaratna, 2000).

${ }^{4}$ We assume that CEOs align, at least partially, their personal reputation with their firms' reputation.
} 
social capital by fostering good relations with external parties such as customers (Walker and Kent, 2009; Lev et al., 2010), employees (Greening and Turban, 2000; Edmans, 2011), investors (Minor and Morgan, 2011), creditors, and suppliers (Maden et al., 2012).CSR reputation contributes to firm value not only through the reputational gain as a reward for positive behavior but also by mitigating the risk of reputational losses emerging from adverse firm-specific events (Peloza, 2006; Minor and Morgan, 2011). This is due to regulators, investors, customers, and other stakeholders trust on companies' explanation and perceived sincerity of proposed remedial activities (Brown, 1998). In sum, we can posit that CSR investment accumulates social capital for the firm and create value as an operational hedging instrument. ${ }^{5}$ Therefore, it indicates that relevant stakeholders provide premium for CSR reputation, which is in line with reputation effects in repeated game. ${ }^{6}$

The operational hedging ability of CSR is studied from different viewpoints. Vanhamme and Grobben (2009) show that firms with long history of CSR have higher ability to counter the adverse effects of a crisis, albeit based on accusations of animal testing. Gregory et al. (2014) consider firms with positive CSR activities as "Green" firms, whereas firms with negative CSR activities are considered as "Toxic" firms. Overall, the results show that CSR activities improve cash flows through the reduction of firm-specific risk, which could be visible either in the form of higher profitability immediately, or in the form of superior long-run

\footnotetext{
${ }^{5}$ We can refer CSR as an operational hedging instrument as it is a non-financial instrument and increases firm value by reducing deadweight costs of financial distress through operational activities. By following the same reasoning, repurchase as flexible pay-out structure (Bonaimé et al., 2014), geographic diversification for MNCs (Allayannis et al., 2001; Kim et al., 2006), and acquisition (Hankins, 2011) are considered as operational hedging in the contemporary finance literature.

${ }^{6}$ In repeated games, agents could try to generate reputation for a specific characteristic in the early stages of the game. In later stage it payoffs if that characteristics improve.
} 
growth prospects (e.g., Choi and Wang, 2009). Godfrey et al. (2009) argue that CSR investment mitigates firm-specific risk triggered by firm-specific adverse events. Based on the case study of firm-specific adverse events, Minor and Morgan (2011) show CSR activities protect firm stock price against loss of reputation following adverse events (see also Herremans et al., 1993; Shiu and Yang, 2017)).

This paper draws on the interaction between signaling theory and reputation effects in repeated game. We argue that when a politically driven economy-wide or industry-wide event occurs, CSR reputation is likely to protect the firm as it does for firm-specific adverse events. We expect that during these uncertain periods, idiosyncratic volatility is lower for firms with accumulated CSR reputation as well as social capital. Therefore, our study highlights an enhanced hedging ability of CSR and depict that social capital can be beneficial for firm value during economy-wide or industry-wide uncertainty. The hedging ability of CSR can affect value in two ways. First, because investors prefer to invest in companies with high CSR reputation (Brown, 1998; Maden et al., 2012), the cost of equity is lower for these firms (El Ghoul et al., 2011). Also, creditors lower the cost of debt for these firms due to lower default risk (Webb, 2005; Kim et al., 2009; Goss and Roberts, 2011). Therefore, high CSR firms have better access to finance at a relatively lower cost of capital stemming from a lower risk premium (Bassen et al., 2006; Cao et al., 2015; Hasan et al., 2017). Since the value of a firm is the present value of future expected cash flows, by reducing the cost of capital, high CSR investment can increase shareholder value (Gregory et al., 2014). Second, Stultz (2002) argues that risk reduction can increase the firm value if the perfect market assumptions are violated. Since capital markets have frictions such as information asymmetry, tax convexity, and financial distress, cash flow volatility is costly (Tufano, 1996; Ağca and Mozumdar, 2008; Hankins, 2011). Therefore, hedging can increase firm value by reducing cash flow variability (Stulz, 1990; Froot et al., 1993), which affects both investment and financial decisions of the firm. 
Hence, by reducing cash flow volatility, CSR reputation can create value as an operational hedging instrument.

\subsection{Operational hedging ability of CSR during political uncertainty}

Political cycles arise in macroeconomic policies in response to myopic behavior of voters. Such political business cycles reflect the incumbents' tendency to manipulate macroeconomic policy in order increase their chances of winning an election by following an inflationary boom and lower unemployment rate prior to the election followed by deflationary policies after the election (Nordhaus, 1975). Meanwhile, the political budget cycle creates a distortion of fiscal policies by lowering taxes and increasing government consumption spending sub-optimally prior to the election (Rogoff, 1987). Hence, while the election is a fundamental mechanism of accountability, the potential policy differences surrounding these cycles and electoral competitiveness can change the firms' business environment and create uncertainty (CanesWrone and Park, 2014; Gulen and Ion, 2016; Baker et al., 2016; Julio and Yook, 2016; Jens, 2017). As stock returns have exposure to systematic economic forces (Fama and French, 1988 1989; Campbell, 1985; Chen, 1991; Bailey and Chung, 1995), political uncertainty augments the expected return volatility around an election. It is empirically evidenced that return volatility is higher in the election year and electoral competitiveness also contributes to the magnitude of this volatility (Pantzalis et al., 2000; Li and Born, 2006; Białkowski et al., 2008; Boutchkova et al., 2012; Pasquariello and Zafeiridou, 2014). In this paper, we argue that as like as firm-specific negative event, investors should also trust firms with high social capital during political uncertainty. For instance, Guiso et al. (2008) posit that shareholders assess the reliability of the firm in addition to risk-return trade-off. We argue that shareholders will place a premium on CSR reputation, which reflects the firm's values and integrity, during times of political uncertainty. Thus, we expect a negative relationship between CSR reputation and stock return volatility during political uncertainty. By considering election year and electoral 
competitiveness (narrow margin of victory) as sources of political uncertainty we formulate our first hypothesis as follows:

Hla: Firm-specific social capital reduces stock return volatility during political uncertainty.

Moreover, electoral uncertainty generated by political factors leads firms to temporarily reduce investment expenditures before the election outcome (Julio and Yook, 2012). This leads to firms holding an option on whether to invest or not. Since the option value of delaying an investment increases with higher uncertainty (Bloom, 2009), firms delay investing until this political uncertainty resolve at the election (Rodrik, 1991). In addition, lower investment is associated with high cash flow volatility (Minton and Schrand, 1999).

We focus on the uncertainty during U.S. gubernatorial elections. Gubernatorial elections engender uncertainty as governors' preferences has impact in shaping state policies (e.g., state budget, tax code, subsidy policies) (Gao and Qi, 2013; Jens, 2013). Consequently, state policy changes have substantial influence in an economic environment where firms operate (Chhaochharia et al., 2012) and, therefore, in their investment and financing policies. Gao and Qi (2013) suggest that investors demand a risk premium for electoral uncertainty arise around U.S. gubernatorial elections. Jens (2013) shows that return volatility is higher for firms headquartered in U.S. gubernatorial election states than firms in other states. In this paper, we expect to find that cash flow volatility is high surrounding the election. As the extant literature shows that high CSR firms are more profitable along with high growth expectation than low CSR firm (Russo and Fouts, 1997; Barnett, 2007; Gregory et al., 2014), we expect the cash flow volatility for high CSR firm is lower during political uncertainty. We argue that in addition to shareholders, other stakeholders (e.g., customers, employees, and the community at large) will also tend to value high CSR firms more during the politically risky period. Hence, we predict that a negative relationship between CSR reputation and cash flow volatility exists during political uncertainty. Our next hypothesis is the following: 
Hlb: Firm-specific social capital reduces cash flow volatility during political uncertainty.

\subsection{Operational hedging ability of CSR reputation during import tariff cuts}

A reduction in import tariffs reduces the entrance cost and relaxes the trade barriers to enter the U.S. product market. Hence, a significant tariff reduction in any industry exogenously increases foreign competition for all domestic firms of that industry (Fresard, 2010). Fresard (2010) argues that the import tariff cut can be treated as exogenous in the year of tariff cut if it increases over the following years. To assess the operational hedging ability of CSR reputation, we exploit this exogenous shift in industry-level import tariffs as a quasi-natural experiment as this macroeconomic shock is exogenous to idiosyncratic risk and CSR investment. Exogenous tariff cuts creates an adverse cash flow shock to all domestic firms in the industry (Kini et al., 2017). In this regard, we argue that this cash flow shock will be felt disproportionately by firms with high CSR reputation. Specifically, during this macroeconomic shock, high CSR firms will enjoy operational hedging benefit of CSR reputation and face lower cash flow volatility than low CSR firms. Thus, we expect a negative relation between CSR reputation and risk (i.e. stock return volatility and cash flow volatility) during years of significant tariff cut. Our final hypotheses are the following:

H2a: Firms' social capital reduces cash flow volatility during significant import tariff cuts.

H2b: Firm's social capital reduces stock return volatility during significant import tariff cuts.

\section{Sample and data}

Our study covers all publicly traded U.S. firms, excluding financial firms (SIC codes 60006999) and utilities (SIC codes 4900-4949), in the Center for Research in the Security Prices (CRSP)/Compustat merged database between 2002 and 2016. We collect firms' overall Environmental, Social, and Governance (ESG) score from Asset4 ESG database provided by Thomson Reuters. Asset4 database provides ESG information for more than 4,300 companies globally (of which 2693 are US firms) since 2002. We gather CSR ratings available for all US 
firms over 2002-2016. For the ESG score, Asset4 collects 900 evaluation points and measure 250s key performance indicators. On the basis of these indicators, scores are measured for 4 pillars: Economic, Social, Environmental, and Corporate Governance. An overall ESG score is measured as the equally weighted score of each pillar. In addition to company-reported data, Asset4 gathers information from NGOs, stock exchange filings and other independent news sources. We collect firms' accounting data from Compustat and stock data from the Centre for Research in Security Prices (CRSP). Data on Gubernatorial elections are hand collected from Wikipedia sources and are verified with state level election resources, upon availability, as in Devos and Rahman (2018). To identify significant tariff cuts we obtain U.S. import data from Schott's International Economics Resource Page. ${ }^{7}$ State-level unemployment rate and annual GDP growth rate are collected from the Bureau of Labor Statistics (bls.gov) and the Bureau of Economic Analysis (bea.gov), respectively. After dropping observations with missing values in our control variables, the final sample consists of 43,631 firms-year observations for 5,814 unique U.S. firms.

We report the descriptive statistics for the main variables in Table 1. Table 1 shows the summary statistics for all sample firms in Panel A, firms with high CSR score in Panel B, firms with low CSR score in Panel C and the firms without CSR score in Panel D. Panel A shows that the mean overall CSR score is 52.56, consistent with Halbritter and Dorfleitner (2015) and Ferrell et al. (2016). For all sample firms, average stock return volatility is 0.5439 , and average cash flow volatility is 0.0681 . Panel B, C and D illustrate that firms with high CSR score has relatively lower average stock return volatility (0.3112) and cash flow volatility (.0247) than low CSR score firms and firms without CSR score.

\footnotetext{
${ }^{7}$ See http://faculty.som.yale.edu/peterschott/sub international.htm
} 


\section{Empirical Results}

\subsection{Baseline regressions}

We test the hedging ability of CSR reputation for stock return volatility and cash flow volatility separately. We rely on the following model to test the hedging ability of social capital during political uncertainty:

$\operatorname{Risk}_{\mathrm{i}, t}=\alpha+\beta_{1} \times C S R_{i, t}+\beta 2 \times$ Political uncertainty $_{t}+\beta 3 \times C S R_{i, t} \times$ Political uncertainty $_{t}+X_{i, t}$ $1+\theta+\gamma+\varepsilon i, t$

where Risk is measured as stock return volatility and alternatively cash flow volatility. We follow Hoberg and Moon (2017) and measure return volatility as the standard deviation of the firms' daily logarithmic returns, multiplied by the square root of 252 trading days over a year. Cash flow volatility at time $t$ is defined as the standard deviation of cash flow to assets for the previous three years, $t$-3 to $t-1$. As in Hoberg and Moon (2017), cash flow is measured as operating income before depreciation. $C S R_{i, t}$ is the overall ESG score of firm $i$ on time $t$. For Political uncertainty, we use two binary variables: (i) Election which is a binary variable equal to one if a gubernatorial election occurred in the firm's state of headquarter on time $t$, and zero otherwise; (ii) Close Election which is a binary variable that takes the value of one if the victory margin of the headquarter state's gubernatorial election is in the lowest quartile, and zero otherwise. $\mathrm{X}$ is a vector of control variables that have been shown in the literature ${ }^{8}$ to affect return and cash flow volatility. ${ }^{9}$ In addition, we follow Jens (2017) to include state GDP growth rate and state unemployment rate to control for the state-level economic conditions. We also add gubernatorial Term Limit as a state level control variable, which is 1 if the incumbent

\footnotetext{
${ }^{8}$ See Vuolteenaho (2002), Bae et al. (2004), Chen et al. (2013), Harjoto et al. (2017), Michaely et al. (2017), Hoberg and Moon (2017), among others.

${ }^{9}$ All control variables are defined in the Appendix.
} 
governor has term limit on the gubernatorial election; otherwise $0 . \theta$ and $\gamma$ are year and industry fixed effects respectively. We follow Jo and Harjoto (2011, 2012) and Jo and $\mathrm{Na}$ (2012) and use contemporaneous values of CSR measures and risk measures (i.e. stock return volatility and cash flow volatility). ${ }^{10}$ Firm-level financial controls, state-level GDP growth rate and unemployment rate are lagged by one year for all specifications.

In line with our arguments, we expect the coefficient on the interaction term $C S R \times$ Political Uncertainty to be negative. Table 2, Panel A presents the OLS estimates for the impact of CSR reputation on stock return volatility, as a proxy for firm risk, during political uncertainty. Columns 1, 3 and 5 show the impact of CSR on return volatility during election years, close elections and post-election years, respectively. To mitigate the concern of omitted variable bias, we add firm-specific financial and state level macroeconomic control variables in columns 2, 4 and 6. In all specifications, it is clear that return volatility is higher in election years and the degree of uncertainty increases during close elections. Column (1) shows that the higher CSR rating reduces the return volatility during election year. The estimated coefficients indicate that firms having headquarters in states which have an upcoming gubernatorial election, have $0.78 \%$ higher return volatility than firms having headquarter in states without an upcoming election. However, for high CSR firms this return volatility difference reduces to $0.01 \%$, suggesting that high CSR reputation has a mitigating effect on stock volatility.

After adding firm and state level control variables, column (2) also confirms that higher CSR rating reduces the return volatility during election year. In column (3), we estimate the

\footnotetext{
${ }^{10}$ Nowadays media cycles become very shorter (Sennett, 1999). So, any good or bad news regarding business firms spread fast (Kirsner, 1998) and can change stakeholder perceptions as well as firm reputation immediately. Due to this reason, the CSR reputation consequences may have immediate impact on firm risk (Orlitzky and Benjamin, 2001).
} 
CSR-risk relation during closely contested elections. The result shows that the hedging ability of CSR reputation remains effective when the degree of uncertainty of election is higher. A one-standard-deviation increase in CSR (29.63) is associated with a $0.89 \%$ decrease in return volatility during closely contested election years, with the average vote margin being $3.18 \%$. Column (4) confirms that high CSR rating reduces return volatility during close elections. We also regress CSR on return volatility during post-election years to assess whether the hedging ability is transient or has a longer-term effect. Our results show that after controling for firm characteristics the uncertainty during post-election year becomes statistically insignificant. This suggests that CSR has a transient heding effect on stock volatility during political uncertainty. Overall, our results suggest that CSR reputation reduces stock return volatility during elections year and especially during close elections when the degree of uncertainty regarding the gubernatorial race is high.

Table 2, Panel B presents the OLS estimates for the impact of CSR reputation on cash flow volatility during political uncertainty. Columns (1), (3) and (5) show that cash flow volatility is positively affected by the election year, closely contested elections and post-election year. Column (3) indicates that CSR reputation reduces cash flow volatility during close elections. Although, these effects become statistically insignificant after we include control variables in column (2), (4) and (6). Overall, we do not find strong evidence that would suggest that CSR reputation reduces cash flow volatility during political uncertainty.

\subsection{Instrumental variable approach}

The relation between CSR and risk can be endogenous. For instance, financially constrained firms lower their investment in CSR (Hong et al., 2012). Morevoer, Albuquerque et al. (2018) argue that higher valuation resulting from lower risk allows the firm to invest more on CSR (see also Orlitzky and Benjamin, 2001). To tackle this endogeneity between risk and CSR, we employ two alternative strategies. First, we use an instrumental variable (IV) 
approach to measure the relation between CSR and risk by instrumenting CSR with a set of instruments. Second, we use industry-level import tariff reductions as a quasi-natural experiment to isolate the causal effect of risk on CSR. In addition to these two steps, we test the effect of CSR reputation across different groups that are categorized based on the CSR score to limit the possibility of spurious correlation.

We use an instrumental variable approach to measure the impact of CSR reputation over stock return volatility and cash flow volatility during political uncertainty. First, we follow the approach of Ferrell et al. (2016) to use the industry peers' average of the endogenous variable as an instrument. Hence, our first instrument is the average CSR rating of all firms in the same industry, excluding the focal firm. The rationale behind this instrument is that CSR performance of other firms in the same industry also systematically influence CSR practices of the focal firm (Ioannou and Serafeim, 2011; Cheng et al., 2014). Our second instrument is the average CSR score of all firms in the state (excluding the focal firm) where the focal firm headquarter is located. Differences in the regional attitude towards CSR practice influence the social performance of the firm (Goss and Roberts, 2011). Rubin (2008) empirically shows that companies with high CSR score tend to be situated in the Democratic (blue) states that vote Democratic in presidential elections, whereas low CSR companies tend to be situated in Republican (red) states. With the same motivation, El Ghoul et al. (2011), Benlemlih (2015) and Dunbar et al. (2017) also use these instrumental variables to instrument CSR. Similarly, we assume that both instruments, which vary across firms since focal firm CSR score is omitted, are exogenous to the contemporaneous CSR score. 
Table 3 reports the 2SLS estimates of the impact of CSR reputation on risk by using both industry and state average CSR as instruments. ${ }^{11}$ Panel A, reports the regression estimates for stock return volatility. Column (1) reports the first stage regression on CSR score. The results show that CSR score has a positive and statistically significant relationship with the instrument. Columns (2) to (7) report the estimates from the second stage regressions. Column (2) confirms that the return volatility for the firms headquartered in states facing gubernatorial election is higher than other U.S. firms and CSR reputation reduces this volatility. Moreover, our results show that CSR's hedging ability persists during closely contested elections. For instance, column (3) shows that a one-standard-deviation increase in CSR score (29.63) is associated with a $6.52 \%$ decrease in return volatility during the election period for firms headquartered in states facing gubernatorial election. According to the estimates of column (5), a one-standarddeviation increase in CSR score is associated with a $10.96 \%$ decrease in return volatility during close elections, which indicates that CSR reputation effect is stronger when the degree of uncertainty is higher. However, both columns (6) and (7) support our earlier findigns that CSR's hedging ability is tranisent. This finding also supports Lins et al. (2017) who find that the impact of CSR on firm performance becomes insignificant after the crisis. To confirm the strength of the instruments, we report the Cragg-Donald Wald F-statistics which supports the validity of the employed instruments. Overall, our IV estimates confirm that CSR reputation can reduce stock return volatility during political uncertainty, albeit, it is a transient effect since it lasts only during the year of political uncertainty.

\footnotetext{
${ }^{11}$ We repeat the 2 SLS estimations with each instrument (indsutry average CSR and state average CSR) separately. The results, presented in appendix (Tables A1 and A2) show that the instruments are also significant individually and most importantly the reuslts remain qualitatively similar and significant (both statistically and economically).
} 
In Panel B of Table 3, we report the 2SLS estimates of the impact of CSR reputation over cash flow volatility during political uncertainty by using both industry and state average CSR as instruments. In column (1), the first stage regression shows that both the instruments have significantly positive association with CSR score. The results of column (2) show that the cash flow volatility of firms having headquarters in upcoming gubernatorial election states is $1.02 \%$ percentage higher than other sample firms. A one standard deviation increase of CSR score hedges this volatility during election year by $1.78 \%$. Similar to our earlier OLS results the impact of CSR during or after elecctions (or closely contested elections) is not statistically signficant when including other control variables to mitigate the concern of omitted variable bias. Boutchkova et al. (2012) argue that the uncertainty regarding future party orientation increases the uncertainty regarding future cash flows and this effect is industry-specific. Also, Julio and Yook (2012) show that firms increase cash holding than usual during the election year on a precautionary basis. We argue that these are the reasons why CSR reputation has no impact on cash flow volatilty during political uncertainty (gubernatorial elections).

\subsection{Tariff cut as exogenous shocks}

We exploit the exogenous shock triggered by tariff cuts as a quasi-natural experiment and employ a difference-in-difference approach to test the causal link between CSR reputation and cash flow volatility. To identify significant import tariff cut rate, we follow Fresard (2010) and Kini et al. (2017). We collect U.S. import data from Schott's International Economics Resource Page spanning 2002-2016. First, the tariff rate for each industry-year observation is calculated as Calculated Duties, divided by Imports by Custom Value. Next, we consider that a significant tariff cut in an industry-year occurs when the tariff rate is reduced by more than twice the average industry-wide tariff rate reduction over our sample period. Similar to Kini et al. (2016), to ensure that large tariff cuts are not temporary changes in tariff rates, we exclude tariff cuts that are followed by large percentage increase in the tariff over the three subsequent years. 
Next, we merge the tariff cur data with the CSR score from Asset4 and firm-level accounting data from Compustat. Because data on tariffs for manufacturing industries, we restrict our focus to these industries. Finally, we create a binary variable for tariff cuts which is equal to one if any industry experiences a significant tariff cut, and zero otherwise. Finally, we estimate the following model:

$\operatorname{Risk}_{i, t}=\alpha+\beta 1 C S R_{i, t}+\beta 2 C U T_{i, t}+\beta 3 C S R_{i, t} \times C U T_{i, t}+Y_{i, t-1}+\sigma+\delta+u_{i, t}$

Here, Risk $k_{i, t}$ is measured as the stock return volatility and alternatively as cash flow volatility of firm $i$ during time $t$. $C U T_{i, t}$ is a binary variable, which is one if any firm experiences a significant tariff cut in period $t$, and zero otherwise. As a first step we want to test whether just having a CSR score can reduce industry-wide economic risk. Therefore, $C S R_{i, t}$ is a binary variable equal to one for firms that have a CSR score and zero otherwise. Then we proceed to test CSR's hedging effectiveness within the reduced sample of firms that have a CSR score. For this case $C S R_{i, t}$ is also a binary variable equal to one for firms with high CSR score and zero for firms with a low CSR score. We identify firms as high or low CSR firms based on the annual mean, median and tercile classifications. For Median classification, we split the set of observations into equal groups on the basis of the median value of CSR by year. Then, the group of firms having high CSR score than median at year $t$ is categorized as high CSR firm and other firms are defined as low CSR firm. For the Mean classification, we follow the same procedure on the basis of mean CSR values by year. For Tercile classification, the set of observations are divided into equal tercile every year based on CSR score. Firms in the $1^{\text {st }}$ tercile are classified as high CSR firm, and those in the $3^{\text {rd }}$ tercile are classified as low CSR firm. $\mathrm{Y}$ is a vector of firms-specific control variables that have been shown in the literature to affect return and cash flow volatility and $\sigma$ and $\delta$ are time and industry fixed effects respectively. If CSR can mitigate firm risk during time of industry-wide economic shocks, we expect the coefficient on the interaction term $C S R \times C U T$ to be negative. 
The results from our estimated regression models on the impact of tariff cut on hedging ability of social capital are reported in Table 4. Panel A presents the results for stock return volatility as a risk measure. Column (1) shows that firms having a CSR score have lower stock return volatility during a tariff shock. This suggests that the reputational effect of firms' social capital can hedge industry-wide risks. Next we proceed to test whether the magnitude of social capital, captured by a high vs low CSRT score has a differentiating effect regarding CSR's hedging effectiveness. Columns (2) to (4) report the estimates for the nominal CSR score, mean, median and tercile classifications of CSR score, respectively. The results from all specifications suggest that although CSR reduces the stock return volatility, the impact of CSR reputation on stock return volatility during significant tariff cut is not statistically significant. Overall, these findings suggest that as far as stock volatility is concerned, the magnitude of CSR has no mitigating impact on firm risk.

Next we repeat our estimations with cash flow volatility as a risk measure. The results reported in Table 4, Panel B show that in all specifications, the marginal effect related to the interaction term between Tariff Shock and CSR is not statistically significant. From this difference-in-difference estimation we find that although CSR reduces stock return volatility and cash flow volatility and is an effective hedge against risk during political uncertainty, CSR reputation is not an effective hedge against firm risk during industry-wide economic shocks.

\section{Conclusion}

In this paper, we assess the hedging ability of firms' social capital during regional political risk and industry-wide economic shocks (import tariff cuts). Our the paper contributes to the literature by investigating the CSR-risk relationship during the times of political uncertainty and industry-wide economic shocks while considering the potential reverse causality between CSR and firm risk. We provide evidence suggesting that firm-specific social capital captured by CSR reputation, has a statistical and economically significant mitigating effect on stock 
return volatility during political uncertainty. However, we do not find strong evidence that CSR reputation can hedge cash flow volatility triggered by political uncertainty. Moreover, our difference-in-difference estimation suggests that CSR is not an effective hedge against risk during indsutry-wide economic shocks. Finally, we find that CSR's mitigating effect on stock volatility during political uncertainty is transient and dissipates following the gubernatorial elections. 


\section{References}

Ağca, Ş. and Mozumdar, A. (2008) 'The impact of capital market imperfections on investmentcash flow sensitivity', Journal of Banking and Finance, 32, pp. 207-216.

Albuquerque, R., Koskinen, Y. and Zhang, C. (2017) 'Corporate Social Responsibility and Firm Risk: Theory and Empirical evidence', European Corporate Governance Institute (ECGI), Working Pa.

Allayannis, B. G., Ihrig, J. and Weston, J. P. (2001) 'Exchange-Rate Hedging : Financial versus Operational Strategies', The American Economic Review, 91(2), pp. 391-395.

Antoni, G. D. and Sacconi, L. (2011) 'Does virtuous circle between social capital and CSR exist? A "network of games" model and some empirical evidence', IDEAS Working Paper Series from RePEc, pp. 1-42.

Bae, K. H., Chan, K. and Ng, A. (2004) 'Investibility and Return Volatility', Journal of Financial Economics, 71(2), pp. 239-263.

Bailey, W. and Chung, Y. P. (1995) 'Exchange Rate Fluctuations, Political Risk, and Stock Returns: Some Evidence from an Emerging Market', The Journal of Financial and Quantitative Analysis, 30(4), pp. 541-561.

Baker, S. R., Bloom, N. and Davis, S. J. (2016) 'Measuring Economic Policy Uncertainty', NBER Working Paper Series, 21633, pp. 1-75.

Barnett, M. L. (2007) 'Stakeholder Influence Capacity and the Variability of Financial Returns to Corporate Social Responsibility', The Academy of Management Review, 32(3), pp. 794-816. (newly added)

Bassen, A., Meyer, K. and Schlange, J. (2006) 'The Influence of Corporate Responsibility on the Cost of Capital An Empirical Analysis', Mimeo, University of Hamburg, Retrieved, pp. $4-40$.

Becchetti, L., Ciciretti, R. and Hasan, I. (2015) 'Corporate social responsibility, stakeholder risk, and idiosyncratic volatility', Journal of Corporate Finance. Elsevier B.V., 35, pp. 297309.

Bernard, A. B., Jensen, J. B. and Schott, P. K. (2006) 'Trade Costs, Firms and Productivity', Journal of Monetary Economics, 53, pp. 917-937.

Białkowski, J., Gottschalk, K. and Wisniewski, T. P. (2008) 'Stock Market Volatility around National Elections', Journal of Banking and Finance, 32, pp. 1941-1953.

Bloom, N. (2009) 'The Impact of Uncertainty Shocks', Econometrica, 77(3), pp. 623-685.

Bonaimé, A. A., Hankins, K. W. and Harford, J. (2014) 'Financial Flexibility, Risk 
Management, and Payout Choice', Review of Financial Studies, 27(4), pp. 1074-1101.

Borghesi, R., Houston, J. F. and Naranjo, A. (2014) 'Corporate socially responsible investments: CEO altruism, reputation, and shareholder interests', Journal of Corporate Finance. Elsevier B.V., 26, pp. 164-181.

Boutchkova, M., Doshi, H., Durnev, A. and Molchanov, A. (2012) 'Precarious Politics and Return Volatility', The Review of Financial Studies, 25(4), pp. 1111-1154.

Branco, M. C. and Rodrigues, L. L. (2006) 'Corporate Social Responsibility and ResourceBased Perspective', Journal of Business Ethics, 69(2), pp. 111-132.

Brown, B. (1998) 'Do Stock Market Investors Reward Companies with Reputations for Social Performance?', Corporate Reputation Review, 1(3), pp. 271-280.

Campbell, J. Y. (1985) 'Stock Returns and the Term Structure', NBER Working Paper, 1626.

Canes-Wrone, B. and Park, J.-K. (2014) 'Elections, Uncertainty and Irreversible Investment', British Journal of Political Science, 44(1), pp. 83-106.

Cao, Y., Myers, J. N., Myers, L. A. and Omer, T. C. (2015) 'Company reputation and the cost of equity capital', Review of Accounting Studies, 20, pp. 42-81.

Chen, N.-F. (1991) 'Financial Investment Opportunities and the Macroeconomy', The Journal of Finance, 46(2), pp. 529-554.

Chen, Z., Du, J., Li, D. and Ouyang, R. (2013) 'Does Foreign Institutional Ownership Increase Return Volatility? Evidence from China', Journal of Banking and Finance. Elsevier B.V., 37, pp. 660-669.

Chhaochharia, V., Korniotis, G. M. and Kumar, A. (2012) Prozac for Depressed States? Effect of Mood on Local Economic Recessions, Working Paper, University of Miami. Available at: http://papers.ssrn.com/sol3/papers.cfm?abstract_id=1814083.

Choi, J. and Wang, H. (2009) 'Stakeholder Relations and the Persistence of Corporate Financial Performance', Strategic Management Journal, 30, pp. 895-907.

Deloitte (2017) 'The 2017 Deloitte Millennial Survey'.

Deloitte Insights (2018) 'The Rise of the Social Enterprise: 2018 Deloitte Global Human Capital Trends'.

Devos, E. and Rahman, S. (2018) 'Labor unemployment insurance and firm cash holdings', Journal of Corporate Finance, 49, pp, 15-31.

Fama, E. F. and French, K. R. (1988) 'Dividend Yields and Expected Stock Returns', Journal of Financial Economics, 22(1), pp. 3-25.

Fama, E. F. and French, K. R. (1989) 'Business Conditions and Expected Returns on Stocks and Bonds', Journal of Financial Economics, 25, pp. 23-49. 
Ferrell, A., Liang, H. and Renneboog, L. (2016) 'Socially responsible firms. Forthcoming', Journal of Financial Economics, 122(3), pp. 585-606.

Fitzgerald, N. (2003) 'CSR : Rebuilding Trust in Business: A Perspective on Corporate Social Responsibility in the 21 st Century', Speech Given by Niall Fitzgerald, Chairman of Unilever at the London Business School as Part of Their Distinguished Speaker Series.

Fombrun, C. and Shanley, M. (1990) 'What's in a Name? Reputation Building and Corporate Strategy', The Academy of Management Journal, 33(2), pp. 233-258.

Francis, J., Huang, A. H., Rajgopal, S. and Zang, A. Y. (2008) 'CEO Reputation and Earnings Quality', Contemporary Accounting Research, 25(1), pp. 109-147.

Fresard, L. (2010) 'Financial Strenght and Product Market Behaior, the Real Effects of Corporate Cash Holding', The Journal of Finance, LXV(3), pp. 1097-1122.

Froot, K. A., Scharfstein, D. S. and Stein, J. C. (1993) 'Risk Management: Coordinating Corporate Investment and Financing Policies', The Journal of Finance, 48(5), pp. 16291658.

Gao, P. and Qi, Y. (2013) 'Political Uncertainty and Public Financing Costs: Evidence from U.S. Municipal Bond Markets', USC FBE Finance Seminar, (574), pp. 1-60.

Guiso, L., Sapienza, P. and Zingales, L. (2008) 'Trusting the Stock Market', The Journal of Finance, 63(6), pp. 2557-2600.

El Ghoul, S., Guedhami, O., Kwok, C. C. Y. and Mishra, D. R. (2011) 'Does corporate social responsibility affect the cost of capital?', Journal of Banking and Finance. Elsevier B.V., 35, pp. 2388-2406.

Godfrey, P. C., Merrill, C. B. and Hansen, J. M. (2009) 'The Relationship between Corporate Social Responsibility and Shareholder Value: An Empirical Test of The Risk Management Hypothesis', Strategic Management Journal, 30, pp. 425-445.

Goss, A. and Roberts, G. S. (2011) 'The Impact of Corporate Social Responsibility on the Cost of Bank Loans', Journal of Banking \& Finance, 35(7), pp. 1794-1810.

Gregory, A., Tharyan, R. and Whittaker, J. (2014) 'Corporate Social Responsibility and Firm Value: Disaggregating the Effects on Cash Flow, Risk and Growth', Journal of Business Ethics, 124(4), pp. 633-657.

Gulen, H. and Ion, M. (2016) 'Policy Uncertainty and Corporate Investment', Review of Financial Studies, 29, pp. 523-564.

Halbritter, G. and Dorfleitner, G. (2015) 'The wages of social responsibility - where are they? A critical review of ESG investing', Review of Financial Economics, 26, pp. 25-35.

Hankins, K. W. (2011) 'How Do Financial Firms Manage Risk? Unraveling the Interaction of 
Financial and Operational Hedging', Management Science, 57(12), pp. 2197-2212.

Harjoto, M., Jo, H. and Kim, Y. (2017) 'Is Institutional Ownership Related to Corporate Social Responsibility? The Nonlinear Relation and Its Implication for Stock Return Volatility', Journal of Business Ethics. Springer Netherlands, 146(1), pp. 77-109.

Hasan, I., Hoi, C.-K., Wu, Q. and Zhang, H. (2017) 'Social Capital and Debt Contracting: Evidence from Bank Loans and Public Bonds', Journal of Financial and Quantitative Analysis, 52(3), pp. 1017-1047. Available at: http://ssrn.com/abstract=2667172.

Hoberg, G. and Moon, S. K. (2017) 'Offshore activities and financial vs operational hedging', Journal of Financial Economics. Elsevier B.V., 125(2), pp. 217-244.

Hong, H., Kubik, J. D. and Scheinkman, J. A. (2012) 'Financial Constraints on Corporate Goodness', NBER Working Paper Series, 18476.

Hur, W. M., Kim, H. and Woo, J. (2014) 'How CSR Leads to Corporate Brand Equity: Mediating Mechanisms of Corporate Brand Credibility and Reputation', Journal of Business Ethics, 125, pp. 75-86.

Idowu, S. O., Louche, C. and Filho, W. L. (2010) 'Innovative Corporate Social Responsibility: An Introduction', in C line Louche, Samuel Idowu, W. F. (ed.) Innovative CSR: From Risk Management to Value Creation. Greenleaf Publishing, pp. 1-9.

Irvine, P. J. and Pontiff, J. (2009) 'Idiosyncratic Return Volatility, Cash Flows, and Product Market Competition', Review of Financial Studies, 22(3), pp. 1149-1177.

Jens, C. E. (2013) 'Political uncertainty and investment: Causal evidence from U.S. gubernatorial elections', Journal of Financial Economics. Elsevier B.V., 124(October 2012), pp. 563-579.

Jens, C. E. (2017) 'Political Uncertainty and Investment: Causal evidence from U.S. Gubernatorial Elections', Journal of Financial Economics. Elsevier B.V., 124, pp. 563-579. Jo, H. and Harjoto, M. A. (2011) 'Corporate Governance and Firm Value: The Impact of Corporate Social Responsibility', Journal of Business Ethics, 103, pp. 351-383.

Jo, H. and Harjoto, M. A. (2012) 'The Causal Effect of Corporate Governance on Corporate Social Responsibility', Journal of Business Ethics, 106, pp. 53-72.

Jo, H. and Na, H. (2012) 'Does CSR Reduce Firm Risk? Evidence from Controversial Industry Sectors', Journal of Business Ethics, 110(4), pp. 441-456.

Julio, B. and Yook, Y. (2012) 'Political Uncertainty and Corporate Investment Cycles', The Journal of Finance, 67(1), pp. 45-83.

Julio, B. and Yook, Y. (2016) 'Policy Uncertainty, Irreversibility, and Cross-border Flows of Capital', Journal of International Economics. Elsevier B.V., 103, pp. 13-26. 
Kim, M., Surroca, J. and Tribo, A. J. (2009) 'The Effect of Social Capital on Financial Capital', Working Paper: Business Economic Series, Wp. 09-02(ISSN: 1989-8843), pp. 1-42.

Kim, Y. S., Mathur, I. and Nam, J. (2006) 'Is operational hedging a substitute for or a complement to financial hedging?', Journal of Corporate Finance, 12, pp. 834-853.

Kini, O., Shenoy, J. and Subramaniam, V. (2017) 'Impact of Financial Leverage on the Incidence and Severity of Product Failures: Evidence from Product Recalls', The Review of Financial Studies, 30(5), pp. 1790-1829.

Kirsner, S. (1998) 'Inside the WSJ Interactive Edition: A Day in the Life of a World Famous Web Site', Editor \& Publisher, pp. 4-9.

Leana, C. R. and Van Buren, H. J. (1999) 'Organizational Social Capital and Employment Practices', Academy of Management Review, 24(3), pp. 538-555.

Leblang, D. and Mukherjee, B. (2005) 'Government Partisanship, Elections, and the Stock Market: Examining American and British Stock Returns, 1930-2000', American Journal of Political Science, 49(4), pp. 780-802.

Li, J. and Born, J. A. (2006) 'Presidential Election Uncertainty and Common Stock Returns in the United States', The Journal of Financial Research, 29(4), pp. 609-622.

Lins, K. V., Servaes, H. and Tamayo, A. (2017) 'Social Capital, Trust, and Firm Performance: The Value of Corporate Social Responsibility during the Financial Crisis', The Journal of Finance, (0), pp. 1-40.

Maden, C., Arıkan, E., Telci, E. E. and Kantur, D. (2012) 'Linking Corporate Social Responsibility to Corporate Reputation: A Study on Understanding Behavioral Consequences', Procedia - Social and Behavioral Sciences, 58, pp. 655-664.

Mcwilliams, A. and Siegel, D. (2001) 'Corporate Social Responsibility : A Theory of the Firm Perspective', Academy of Management Journal, 26(1), pp. 117-127.

Michaely, R., Rossi, S. and Weber, M. (2017) 'The Information Content of Dividends: Safer Profits, Not Higher Profits', Chicago Booth Research Paper 17-30; Fama-Miller Working Paper. Available at SSRN: https://ssrn.com/abstract $=3064029$.

Milbourn, T. T. (2003) 'CEO reputation and stock-based compensation', Journal of Financial Economics, 68, pp. 233-262.

Miller, D., Lee, J., Chang, S. and Le Breton-Miller, I. (2009) 'Filling the Institutional Void: The Social Behavior and Performance of Family vs Non-Family Technology Firms in Emerging Markets', Journal of International Business Studies, 40, pp. 802-817.

Minor, D. and Morgan, J. (2011) 'CSR as Reputation Insurance: Primum Non Nocere', California Management Review, 53(3), pp. 40-59. Available at: 
http://escholarship.org/uc/item/7258w42x\%5CnCopyright.

Minton, B. A. and Schrand, C. (1999) 'The Impact of Cash Flow Volatility on Discretionary Investment and the Costs of Debt and Equity Financing', Journal of Financial Economics, 54, pp. 423-460.

Nordhaus, W. D. (1975) 'The Political Business Cycle', The Review of Economic Studies, 42(2), pp. 169-190.

Orlitzky, M. and Benjamin, J. D. (2001) 'Corporate Social Performance and Firm Risk: A Meta-analysis', Business \& Society, 40, pp. 369-396.

Pantzalis, C., Stangeland, D. A. and Turtle, H. J. (2000) 'Political Elections and the Resolution of Uncertainty: The International Evidence', Journal of Banking and Finance, 24, pp. 15751604.

Pasquariello, P. and Zafeiridou, C. (2014) 'Political Uncertainty and Financial Market Quality', Ross School of Business Working Paper, Working Pa.

Peloza, J. (no date) 'Corporate Social Responsibility as Reputation Insurance'.

Porter, M. E. and Kramer, M. R. (2006) 'Strategy \& Society: The Link Between Competitive Advantage and Corporate Social Responsibility', Harvard Business Review, 84(12), pp. 7892.

Putnam, R. D. (1993) ‘Making Democracy Work : Civic Traditions in Modern Italy', Princeton NJ: Princeton University Press. Princeton University Press, Princeton, NJ.

Rindova, V. P. and Fombrun, C. J. (1999) 'Constructing Competitive Advantage: The Role of Firm-Constituent Interactions', Strategic Management Journal, 20(8), pp. 691-710.

Rindova, V. P., Williamson, I. O., Petkova, A. P. and Sever, J. M. (2005) 'Being Good or Being Known: An Empirical Examination of the Dimensions, Antecedents, and Consequences of Organizational Reputation', The Academy of Management Journal, 48(6), pp. 1033-1049.

Rodrik, D. (1991) 'Policy Uncertainty and Private Investment in Developing Countries', Journal of Development Economics, 36, pp. 229-242.

Rogoff, K. (1987) ‘Equilibrium Political Budget Cycles', NBER WORKING PAPER SERIES, (2428), pp. 1-37.

Rogoff, K. and Sibert, A. (1988) 'Elections and Macroeconomic Policy Cycles', The Review of Economic Studies, 55(1), pp. 1-16.

Russo, M. V. and Fouts, P. A. (1997) 'A Resource-Based Perspective on Corporate Environmental Performance and Profitability', The Academy of Management Journal, 40(3), pp. 534-559.

Sennett, F. (1999) 'Coming Clean on Maralinga', Editor \& Publisher, p. 38. 
Servaes, H. and Tamayo, A. (2017) 'The Role of Social Capital in Corporations: A Review', Oxford Review of Economic Policy, 33(2), pp. 201-220.

Shiu, Y.-M. and Yang, S.-L. (2017) 'Does engagement in corporate social responsibility provide strategic insurance-like effects?', Strategic Management Journal, 38, pp. 455-470.

Stultz, R. M. (2002) Risk management and derivatives. Newyork: Southwestern College Publications.

Stulz, R. (1990) 'Managerial discretion and optimal financing policies', Journal of Financial Economics, 26, pp. 3-27.

Surroca, J., Tribo, J. A. and Waddock, S. (2010) 'Corporate Responsibility and Financial Performance: The Role of Intangible Resources', Strategic Management Journal, 31, pp. 463-490.

Tufano, P. (1996) 'Who Manages Risk? An Empirical Examination of Risk Management Practices in the Gold Mining Industry', The Journal of Finance, 51(4), pp. 1097-1137.

Turban, D. B. and Greening, D. W. (1997) 'Corporate Social Performance and Organizational Attractiveness to Prospective Employees', The Academy of Management Journal, 40(3), pp. $658-672$.

Uphoff, N. and Wijayaratna, C. M. (2000) 'Demonstrated Benefits from Social Capital: The Productivity of Farmer Organizations in Gal Oya, Sri Lanka', World Development, 28(11), pp. $1875-1890$.

Vanhamme, J. and Grobben, B. (2009) 'Too good to be true! The Effectiveness of CSR History in Countering Negative Publicity', Journal of Business Ethics, 85(SUPPL. 2), pp. 273-283.

Vuolteenaho, T. (2002) 'What Drives Firm-Level Stock Returns?', The Journal of Finance, 57(1), pp. 233-264.

Webb, E. (2005) 'Agency Costs, Leverage, and Corporate Social Responsibility: A Test of Causality', Financial Decisions, Fall(1), pp. 1-19. 


\section{Table 1. Summary statistics}

This table consists of summary statistics for our sample of all publicly traded U.S. firms in CRSP/Compustat between 2002 and 2016. We exclude financial firms (SIC codes 6000-6999) and utilities (SIC codes 4900-4949). Summary statistics for all sample firms, firms with high CSR score, firms with low CSR score and the firms without CSR score are reported in Panel $\mathrm{A}, \mathrm{B}, \mathrm{C}$, and D respectively. Firms are classified as high and low CSR based on Tercile classification. All variables are defined in the Appendix. All continuous variables are winsorized at the $1 \%$ and $99 \%$ tails.

\section{Panel A: All Firms}

$\begin{array}{lccccc} & \boldsymbol{N} & \text { Mean } & \boldsymbol{S D} & \text { Min } & \text { Max } \\ \text { CSR } & 9,766 & 52.5579 & 29.6292 & 3.2500 & 98.7200 \\ \text { Return Volatility } & 43,631 & 0.5439 & 0.3142 & 0.0502 & 2.1670 \\ \text { Cash Flow Volatility } & 41,903 & 0.0681 & 0.1100 & 0.0001 & 0.7466 \\ \text { Market-to-Book } & 43,631 & 1.5760 & 1.6674 & 0.0279 & 12.2359 \\ \text { Leverage } & 43,631 & 0.1745 & 0.2001 & 0.0000 & 0.9003 \\ \text { Operating Margin } & 43,631 & -0.5655 & 3.8855 & -33.1927 & 0.7835 \\ \text { Investment } & 43,631 & 0.0916 & 0.2421 & -1.0486 & 1.2518 \\ \text { Sales Growth } & 43,631 & 0.0809 & 0.3397 & -1.2074 & 1.5404 \\ \text { Profitability } & 43,631 & -0.0496 & 0.2772 & -1.9055 & 0.3092 \\ \text { Cash } & 41,903 & 0.1550 & 0.1732 & 0.0001 & 0.8740 \\ \text { Negative Equity } & 43,631 & 0.0478 & 0.2133 & 0.0000 & 1.0000 \\ \text { Term Limit } & 43,631 & 0.0430 & 0.2028 & 0.0000 & 1.0000 \\ \Delta \text { GDP } & 43,631 & 0.0388 & 0.0274 & -0.0565 & 0.1295 \\ \text { Unemployment } & 43,631 & 6.3382 & 1.9617 & 3.2000 & 12.2000\end{array}$

Panel B: High CSR Firm (Based on Tercile Classification)

$\begin{array}{lccccc} & \boldsymbol{N} & \text { Mean } & \text { SD } & \text { Min } & \text { Max } \\ \text { CSR } & 3,248 & 87.4654 & 8.9516 & 50.0300 & 98.7200 \\ \text { Return Volatility } & 3,248 & 0.3112 & 0.1522 & 0.0963 & 1.3228 \\ \text { Cash Flow Volatility } & 3,139 & 0.0247 & 0.0386 & 0.0003 & 0.7466 \\ \text { Market-to-Book } & 3,248 & 1.5421 & 1.2327 & 0.0279 & 12.2359 \\ \text { Leverage } & 3,248 & 0.2174 & 0.1392 & 0.0000 & 0.9003 \\ \text { Operating Margin } & 3,248 & 0.1883 & 0.1644 & -3.6281 & 0.7402 \\ \text { Investment } & 3,248 & 0.0529 & 0.1418 & -1.0486 & 1.2518 \\ \text { Sales Growth } & 3,248 & 0.0422 & 0.1692 & -1.2074 & 1.5404 \\ \text { Profitability } & 3,248 & 0.0652 & 0.0877 & -1.9055 & 0.3092 \\ \text { Cash } & 3,139 & 0.0962 & 0.0814 & 0.0001 & 0.7874 \\ \text { Negative Equity } & 3,248 & 0.0262 & 0.1597 & 0.0000 & 1.0000\end{array}$

Panel C: Low CSR Firm (Based on Tercile Classification)

$\begin{array}{lccccc} & \boldsymbol{N} & \text { Mean } & \text { SD } & \text { Min } & \text { Max } \\ \text { CSR } & 3,262 & 20.8853 & 8.9451 & 3.2500 & 40.8700 \\ \text { Return Volatility } & 3,262 & 0.4122 & 0.2110 & 0.1101 & 2.0882 \\ \text { Cash Flow Volatility } & 3,151 & 0.0448 & 0.0752 & 0.0002 & 0.7466 \\ \text { Market-to-Book } & 3,262 & 1.8768 & 1.8697 & 0.0279 & 12.2359\end{array}$




$\begin{array}{lccccc}\text { Leverage } & 3,262 & 0.2301 & 0.2114 & 0.0000 & 0.9003 \\ \text { Operating Margin } & 3,262 & -0.1573 & 2.7726 & -33.1927 & 0.7835 \\ \text { Investment } & 3,262 & 0.1346 & 0.2319 & -1.0486 & 1.2518 \\ \text { Sales Growth } & 3,262 & 0.1115 & 0.3012 & -1.2074 & 1.5404 \\ \text { Profitability } & 3,262 & 0.0179 & 0.1723 & -1.9055 & 0.3092 \\ \text { Cash } & 3,151 & 0.1300 & 0.1377 & 0.0001 & 0.8740 \\ \text { Negative Equity } & 3,262 & 0.0490 & 0.2160 & 0.0000 & 1.0000\end{array}$

Panel D: No CSR Firm

$\begin{array}{lccccc} & \boldsymbol{N} & \text { Mean } & \text { SD } & \text { Min } & \text { Max } \\ \text { Return Volatility } & 33,865 & 0.5956 & 0.3241 & 0.0502 & 2.1670 \\ \text { Cash Flow Volatility } & 32,465 & 0.0782 & 0.1194 & 0.0001 & 0.7466 \\ \text { Market-to-Book } & 33,865 & 1.5466 & 1.6963 & 0.0279 & 12.2359 \\ \text { Leverage } & 33,865 & 0.1612 & 0.2037 & 0.0000 & 0.9003 \\ \text { Operating Margin } & 33,865 & -0.7462 & 4.2992 & -33.1927 & 0.7835 \\ \text { Investment } & 33,865 & 0.0920 & 0.2553 & -1.0486 & 1.2518 \\ \text { Sales Growth } & 33,865 & 0.0825 & 0.3644 & -1.2074 & 1.5404 \\ \text { Profitability } & 33,865 & -0.0766 & 0.3015 & -1.9055 & 0.3092 \\ \text { Cash } & 32,465 & 0.1673 & 0.1855 & 0.0001 & 0.8740 \\ \text { Negative Equity } & 33,865 & 0.0507 & 0.2195 & 0.0000 & 1.0000\end{array}$




\section{Table 2. The relationship between CSR reputation and risk during Political Uncertainty}

This table reports OLS estimates of CSR reputation and risk. As risk measure, we use return volatility and cash flow volatility as dependent variable in Panel A and B respectively. Stock return volatility is the standard deviation of the firms' daily logarithmic returns, multiplied by the square root of 252 trading days. Cash flow volatility, which is standard deviation of cash flow to assets for the previous three years. To measure political uncertainty, we use two binary variables: (i) Election, a binary variable equal to one if a gubernatorial election occurred in the firm's state of headquarters on time $t$, and zero otherwise; (ii) Close, a binary variable equal to one if the vote margin between top two candidates remains in the lowest quartile, and zero otherwise. Post-election is a binary variable equal to one if a gubernatorial election occurred in the firm's state of headquarters lagged by a year $(t-1)$. Values of risk and CSR measures are contemporaneous. All firm-level financial controls, state-level GDP growth rate and unemployment rate are lagged by one year. All variables are defined in the Appendix. All regressions include industry and year fixed effects. We use heteroscedasticity robust standard errors clustered at the firm level, which are reported in parentheses. ***,**, and * indicate significance at 1\%, 5\%, and 10\% level, respectively. All continuous variables are winsorized at the $1 \%$ and $99 \%$ tails.

\section{Panel A: Stock Return Volatility}

$$
\text { (1) }
$$

(2)

(3)

(4)

(5)

$(6)$

CSR

Election

$\begin{array}{cc}-0.0033 * * * & -0.0030 * * * \\ (0.0001) & (0.0001) \\ 0.0078 * & 0.0123 * * * \\ (0.0042) & (0.0043) \\ 0.0001 * & 0.0001 * * \\ (0.0001) & (0.0001)\end{array}$

Close Election

$\begin{array}{cc}0.0249 * * * & 0.0266 * * * \\ (0.0066) & (0.0064) \\ -0.0003 * * & -0.0003 * * \\ (0.0001) & (0.0001)\end{array}$

Post-election

$\begin{array}{cc}0.0066 * & 0.0053 \\ (0.0037) & (0.0037) \\ 0.0003 * * * & 0.0003 * * * \\ (0.0000) & (0.0000)\end{array}$

Market-to-Book

$-0.0096^{* * *}$

$-0.0096 * * *$

$-0.0096 * * *$ 


\begin{tabular}{|c|c|c|c|c|c|c|}
\hline & & $(0.0013)$ & & $(0.0013)$ & & $(0.0013)$ \\
\hline \multirow[t]{2}{*}{ Leverage } & & $-0.0952 * * *$ & & $-0.0950 * * *$ & & $-0.0952 * * *$ \\
\hline & & $(0.0134)$ & & $(0.0134)$ & & $(0.0134)$ \\
\hline \multirow[t]{2}{*}{ Operating Margin } & & $-0.0132 * * *$ & & $-0.0132 * * *$ & & $-0.0132 * * *$ \\
\hline & & $(0.0006)$ & & $(0.0006)$ & & $(0.0006)$ \\
\hline \multirow[t]{2}{*}{ Investment } & & $-0.0534 * * *$ & & $-0.0536 * * *$ & & $-0.0534 * * *$ \\
\hline & & $(0.0077)$ & & $(0.0076)$ & & $(0.0077)$ \\
\hline \multirow[t]{2}{*}{ Sales Growth } & & 0.0002 & & 0.0001 & & 0.0000 \\
\hline & & $(0.0054)$ & & $(0.0054)$ & & $(0.0054)$ \\
\hline \multirow[t]{2}{*}{ Negative Equity } & & $0.2589 * * *$ & & $0.2588 * * *$ & & $0.2587 * * *$ \\
\hline & & $(0.0129)$ & & $(0.0129)$ & & $(0.0129)$ \\
\hline \multirow[t]{2}{*}{ Term Limit } & & $-0.0266 * * *$ & & $-0.0253 * * *$ & & $-0.0204 * * *$ \\
\hline & & $(0.0065)$ & & $(0.0061)$ & & $(0.0060)$ \\
\hline \multirow[t]{2}{*}{$\Delta \mathrm{GDP}$} & & 0.0523 & & 0.0901 & & 0.0472 \\
\hline & & $(0.0764)$ & & $(0.0763)$ & & $(0.0765)$ \\
\hline \multirow[t]{2}{*}{ Unemployment } & & $0.0066^{* * *}$ & & $0.0067 * * *$ & & $0.0066^{* * *}$ \\
\hline & & $(0.0019)$ & & $(0.0019)$ & & $(0.0019)$ \\
\hline \multirow[t]{2}{*}{ Constant } & $0.6396^{* * *}$ & $0.6338 * * *$ & $0.6366^{* * *}$ & $0.6321 * * *$ & $0.6467 * * *$ & $0.6443 * * *$ \\
\hline & $(0.0415)$ & $(0.0401)$ & $(0.0416)$ & $(0.0402)$ & $(0.0415)$ & $(0.0401)$ \\
\hline Observations & 43,631 & 43,631 & 43,631 & 43,631 & 43,631 & 43,631 \\
\hline Industry FE & YES & YES & YES & YES & YES & YES \\
\hline Year FE & YES & YES & YES & YES & YES & YES \\
\hline Adj R-squared & 0.296 & 0.352 & 0.296 & 0.352 & 0.296 & 0.352 \\
\hline
\end{tabular}


Panel B: Cash Flow Volatility

$$
\text { (1) }
$$

(2)

CSR

Election

CSR*Election

Close Election

CSR* Close Election

Post-election

CSR* Post-election

Market-to-Book

Leverage

Profitability

Cash

Investment

Negative Equity

$\begin{array}{cc}-0.0007 * * * & -0.0002 * * * \\ (0.0000) & (0.0000) \\ 0.0045 * * * & 0.0014 \\ (0.0015) & (0.0014) \\ -0.0000 & 0.0000 \\ (0.0000) & (0.0000)\end{array}$

$\begin{array}{cc}0.0096^{* * *} & 0.0027 \\ (0.0024) & (0.0019) \\ -0.0001^{* *} & -0.0000 \\ (0.0000) & (0.0000)\end{array}$

$0.0035 * * \quad 0.0013$

$(0.0016) \quad(0.0013)$

$-0.0000 \quad-0.0000$

(0.0000) (0.0000)

$0.0103 * * * \quad 0.0103 * * *$

(0.0007)

$-0.0200 * * *$

$(0.0042)$

$-0.1763 * * *$

(0.0045)

$0.1081 * * *$

$(0.0064)$

$0.0073 * *$

(0.0033)

$0.0306^{* * *}$
$(0.0007)$

$-0.0200 * * *$

(0.0042)

$-0.1764 * * *$

(0.0045)

$0.1081 * * *$

(0.0064)

$0.0073 * *$

(0.0033)

$0.0306^{* * * *}$ 


\begin{tabular}{|c|c|c|c|c|c|c|}
\hline & & $(0.0039)$ & & $(0.0039)$ & & $(0.0039)$ \\
\hline \multirow[t]{2}{*}{ Term Limit } & & -0.0019 & & -0.0018 & & -0.0013 \\
\hline & & $(0.0020)$ & & $(0.0019)$ & & (0.0019) \\
\hline \multirow[t]{2}{*}{$\Delta \mathrm{GDP}$} & & $-0.0422 *$ & & -0.0385 & & $-0.0429 *$ \\
\hline & & $(0.0247)$ & & $(0.0247)$ & & $(0.0246)$ \\
\hline \multirow[t]{2}{*}{ Unemployment } & & -0.0002 & & -0.0002 & & -0.0002 \\
\hline & & $(0.0006)$ & & $(0.0006)$ & & $(0.0006)$ \\
\hline \multirow[t]{2}{*}{ Constant } & $0.0427 * * *$ & $0.0217 * * *$ & $0.0427 * * *$ & $0.0217 * * *$ & $0.0464 * * *$ & $0.0228 * * *$ \\
\hline & $(0.0081)$ & $(0.0066)$ & $(0.0081)$ & $(0.0065)$ & $(0.0081)$ & $(0.0065)$ \\
\hline Observations & 41,903 & 41,903 & 41,903 & 41,903 & 41,903 & 41,903 \\
\hline Industry FE & YES & YES & YES & YES & YES & YES \\
\hline Year FE & YES & YES & YES & YES & YES & YES \\
\hline Adj R-squared & 0.141 & 0.458 & 0.141 & 0.458 & 0.141 & 0.458 \\
\hline
\end{tabular}


Table 3. The relationship between CSR reputation and risk during Political Uncertainty

This table presents the results of instrumental variable (IV) approach, which estimates the relationship between CSR reputation and risk during political uncertainty over the sample period of 2002-2016. As risk measure, we use return volatility and cash flow volatility as dependent variable in Panel A and B respectively. Stock return volatility is the standard deviation of the firms' daily logarithmic returns, multiplied by the square root of 252 trading days. Cash flow volatility, which is standard deviation of cash flow to assets for the previous three years. CSR is the overall ESG score instrumented with two instruments jointly: the average CSR rating for each state-year pair and industry-year pair. The results of $1^{\text {st }}$ stage are presented in column 1. Column 2, 4 and 6 contains results of $2^{\text {nd }}$ stage regression without control variables. In columns 3,5 and 7 , we report the $2^{\text {nd }}$ stage regression outcomes with control variables. To measure political uncertainty, we use two binary variables: (i) Election, a binary variable equal to one if a gubernatorial election occurred in the firm's state of headquarters on time $t$, and zero otherwise; (ii) Close, a binary variable equal to one if the vote margin between top two candidates remains in the lowest quartile, and zero otherwise. Post-election is a binary variable equal to one if a gubernatorial election occurred in the firm's state of headquarters lagged by a year $(t-1)$. Values of risk and CSR measures are contemporaneous. All firm-level financial controls, state-level GDP growth rate, and unemployment rate are lagged by one year. All variables are defined in the Appendix. All regressions include industry and year fixed effects. We use heteroscedasticity robust standard errors clustered at the firm level, which are reported in parentheses. $* * *, * *$, and $*$ indicate significance at $1 \%, 5 \%$, and $10 \%$ level, respectively. All continuous variables are winsorized at the $1 \%$ and $99 \%$ tails.

Panel A: Stock return volatility - Industry and State Average CSR as Instruments

(1) (2) (3)

(5)

(6)

(7)

$\begin{array}{lc}\text { Industry Average CSR } & 0.1970 * * * \\ & (0.0373) \\ \text { State Average CSR } & 0.2939 * * * \\ & (0.0926)\end{array}$

CSR

(0.0926)

Election

CSR*Election

Close Election

$\begin{array}{cc}-0.0071 * * * & -0.0064 * * * \\ (0.0010) & (0.0011) \\ 0.0330 * * * & 0.0358 * * * \\ (0.0070) & (0.0069) \\ -0.0024 * * * & -0.0022 * * * \\ (0.0004) & (0.0004)\end{array}$

$0.0600 * * * \quad 0.0664 * * *$

(0.0120) (0.0120) 
CSR* Close Election

Post-election

$\begin{array}{cc}-0.0034 * * * & -0.0037 * * * \\ (0.0009) & (0.0009)\end{array}$

CSR* Post-election

Market-to-Book

Operating Margin

Investment

Sales Growth

Negative Equity

Term Limit

$\Delta$ GDP

Unemployment

Observations

Industry FE

Year FE

Cragg-Donald Wald

$$
\begin{gathered}
1.0837 * * * \\
(0.1614) \\
13.7432 * * * \\
(1.4961) \\
0.6228 * * * \\
(0.0516) \\
-3.2970 * * * \\
(0.5007) \\
-2.5651 * * * \\
(0.2802) \\
-8.8441 * * * \\
(0.9852) \\
-0.7257 \\
(0.5542) \\
-8.3323 \\
(8.0094) \\
0.4454 \\
(0.3028) \\
-2.5605 \\
(10.6990)
\end{gathered}
$$

$-0.0054 * * *$

$$
\text { (0.0019) }
$$$$
-0.0383^{*}
$$$$
\text { (0.0211) }
$$$$
-0.0105 * * *
$$$$
\text { (0.0010) }
$$$$
-0.0671 * * *
$$$$
\text { (0.0085) }
$$$$
-0.0102 *
$$$$
(0.0061)
$$

$0.2224 * * *$

(0.0165)

(0.0073)

0.0024

(0.0826)

$0.0090 * * *$

(0.0024)

$0.6418 * * *$

(0.0777)

(0.0727)
$-0.0285 * * *$

$-0.0056^{* * *}$

(0.0019)

$-0.0372 *$

(0.0211)

$-0.0105 * * *$

(0.0010)

$-0.0673 * * *$

$(0.0085)$

$-0.0098$

(0.0061)

$0.2224 * * *$

(0.0165)

$-0.0332 * * *$

(0.0068)

0.0801

(0.0828)

$0.0095^{* * *}$

(0.0024)

$0.6079 * * *$

43,631
YES
YES
143.2

$0.6423 * * *$

(0.0715)
0.0079

$(0.0059) \quad(0.0058)$

$-0.0001 \quad-0.0001$

(0.0003) (0.0003)

$-0.0055^{* * * *}$

(0.0019)

$-0.0390 *$

(0.0210)

$-0.0106 * * *$

(0.0010)

$-0.0670 * * *$

(0.0085)

$-0.0102 *$

(0.0061)

$0.2229 * * *$

(0.0164)

$-0.0242 * * *$

(0.0064)

0.0016

(0.0828)

$0.0091 * * *$

(0.0024)

$0.6641 * * *$

$0.6361 * * *$

(0.0713)

Panel B: Cash Flow Volatility- Industry and State Average CSR as Instruments 
Industry Average CSR

$0.1808 * * *$ (0.0357)

$0.2231 * *$ (0.0909)

CSR

Election

CSR*Election

Close Election

\section{CSR* Close Election}

Post-election

CSR $*$ Post-election

Market-to-Book

\section{$1.5925 * * *$}

(0.1628)

Leverage

Profitability

$11.7204 * * *$

(1.5420)

$13.8050 * * *$

(0.8129)

Cash

Investment

Negative Equity

$\begin{array}{cc}-0.0030 * * * & -0.0010 * * * \\ (0.0005) & (0.0003) \\ 0.0102 * * * & 0.0026 \\ (0.0025) & (0.0021) \\ -0.0006 * * * & -0.0001 \\ (0.0002) & (0.0001)\end{array}$

$0.0170 * * * \quad 0.0033$

$(0.0042) \quad(0.0032)$

$-0.0006 * * \quad 0.0000$

(0.0003) (0.0002)

$0.0115 * * *$
$(0.0008)$
$-0.0104 *$
$(0.0055)$
$-0.1648 * * *$
$(0.0060)$
$0.0952 * * *$
$(0.0079)$
0.0021
$(0.0037)$
$0.0264 * * *$
$(0.0042)$

$\begin{array}{cc}-0.0031 * * * & -0.0010 * * * \\ (0.0005) & (0.0003) \\ & \\ & \\ & \\ 0.0170 * * * & 0.0033 \\ (0.0042) & (0.0032) \\ -0.0006 * * & 0.0000 \\ (0.0003) & (0.0002)\end{array}$

$\begin{array}{cc}0.0043 * & 0.0014 \\ (0.0025) & (0.0020) \\ -0.0001 & -0.0000 \\ (0.0001) & (0.0001) \\ & 0.0115 * * * \\ & (0.0008) \\ & -0.0105 * \\ & (0.0055) \\ & -0.1649 * * * \\ & (0.0060) \\ & 0.0953 * * * \\ & (0.0079) \\ & 0.0022 \\ & (0.0037) \\ & 0.0264 * * \\ & (0.0042)\end{array}$




\begin{tabular}{|c|c|c|c|c|c|c|c|}
\hline Term Limit & $\begin{array}{c}-1.0414^{*} \\
(0.5512)\end{array}$ & & $\begin{array}{l}-0.0030 \\
(0.0021)\end{array}$ & & $\begin{array}{c}-0.0029 \\
(0.0020)\end{array}$ & & $\begin{array}{l}-0.0023 \\
(0.0019)\end{array}$ \\
\hline$\Delta \mathrm{GDP}$ & $\begin{array}{l}-8.7576 \\
(8.0219)\end{array}$ & & $\begin{array}{c}-0.0512 * * \\
(0.0257)\end{array}$ & & $\begin{array}{c}-0.0465 * \\
(0.0258)\end{array}$ & & $\begin{array}{c}-0.0517 * * \\
(0.0256)\end{array}$ \\
\hline Unemployment & $\begin{array}{c}0.7168 * * \\
(0.3028)\end{array}$ & & $\begin{array}{c}0.0005 \\
(0.0007)\end{array}$ & & $\begin{array}{c}0.0005 \\
(0.0007)\end{array}$ & & $\begin{array}{c}0.0005 \\
(0.0007)\end{array}$ \\
\hline Constant & $\begin{array}{c}-2.3963 \\
(10.8067)\end{array}$ & $\begin{array}{c}0.0500 \\
(0.0328)\end{array}$ & $\begin{array}{l}0.0196 * \\
(0.0117)\end{array}$ & $\begin{array}{c}0.0509 \\
(0.0323)\end{array}$ & $\begin{array}{c}0.0200 * \\
(0.0116)\end{array}$ & $\begin{array}{l}0.0570 * \\
(0.0323)\end{array}$ & $\begin{array}{l}0.0214^{*} \\
(0.0115)\end{array}$ \\
\hline $\begin{array}{l}\text { Observations } \\
\text { Industry FE } \\
\text { Year FE } \\
\text { Cragg-Donald Wald }\end{array}$ & $\begin{array}{l}41,903 \\
\text { YES } \\
\text { YES }\end{array}$ & $\begin{array}{c}41,903 \\
\text { YES } \\
\text { YES } \\
146.4\end{array}$ & $\begin{array}{l}41,903 \\
\text { YES } \\
\text { YES } \\
95.85\end{array}$ & $\begin{array}{c}41,903 \\
\text { YES } \\
\text { YES } \\
147.1 \\
\end{array}$ & $\begin{array}{l}41,903 \\
\text { YES } \\
\text { YES } \\
96.73\end{array}$ & $\begin{array}{c}41,903 \\
\text { YES } \\
\text { YES } \\
146.8\end{array}$ & $\begin{array}{c}41,903 \\
\text { YES } \\
\text { YES } \\
96.44\end{array}$ \\
\hline
\end{tabular}




\section{Table 4: How CSR affects firm risk during tariff cuts.}

This table presents the relationship between CSR reputation and risk during import tariff cuts over the sample period of 2002-2016. Treatment firms are firms that belong to the industry which experience a tariff cut shock during 2002-2016. As risk measure, we use return volatility and cash flow volatility as dependent variable in Panel A and B respectively. Stock return volatility is the standard deviation of the firms' daily logarithmic returns multiplied by the square root of 252 trading days. Cash flow volatility is standard deviation of cash flow to assets for the previous three years. CSR/No CSR is a binary variable equal to one for firms that have a CSR score and zero otherwise. CSR score is the continuous score for the sub-sample of firms that have a CSR score. High CSR Score (Mean) is a binary variable that takes the value of one for those firms with a CSR score that is higher than the annual mean CSR score in year $t$, excluding firms that have no CSR score, and zero otherwise. High CSR Score (Median) is a binary variable that takes the value of one for those firms with a CSR score that is higher than the annual median CSR score in year $t$, excluding firms that have no CSR score, and zero otherwise. High CSR Score (Median) is a binary variable that takes the value of one for those firms with a CSR score that is in the top tercile of the annual CSR score in year $t$, excluding firms that have no CSR score, and zero otherwise. Tariff cut is a binary variable, which is equal to one if the annual percentage drop of the import tariff rate is twice the industry average, and zero otherwise. Values of risk and CSR measures are contemporaneous. All firm-level financial controls, state-level GDP growth rate, and unemployment rate are lagged by one year. All regressions include industry and year fixed effects. We use heteroscedasticity robust standard errors clustered at the firm level, which are reported in parentheses. ***,**, and * indicate significance at $1 \%, 5 \%$, and $10 \%$ level, respectively. All continuous variables are winsorized at the $1 \%$ and $99 \%$ tails.

\section{Panel A: Stock Return Volatility}

(1)

\begin{tabular}{|c|c|c|c|c|c|}
\hline & $\begin{array}{c}\text { CSR/No } \\
\text { CSR }\end{array}$ & CSR Score & $\begin{array}{c}\text { High CSR } \\
\text { Score } \\
\text { (Mean) }\end{array}$ & $\begin{array}{c}\text { High CSR } \\
\text { Score } \\
\text { (Median) }\end{array}$ & $\begin{array}{c}\text { High CSR } \\
\text { Score } \\
\text { (Tercile) }\end{array}$ \\
\hline CSR & $\begin{array}{c}-0.2125 * * * \\
(0.0078)\end{array}$ & $\begin{array}{c}-0.0015 * * * \\
(0.0001)\end{array}$ & $\begin{array}{c}-0.0678 * * * \\
(0.0077)\end{array}$ & $\begin{array}{c}-0.0699 * * * \\
(0.0077)\end{array}$ & $\begin{array}{c}-0.1033 * * * \\
(0.0101)\end{array}$ \\
\hline Tariff CUT & $\begin{array}{c}-0.1302 * * * \\
(0.0471)\end{array}$ & $\begin{array}{l}-0.0113 \\
(0.0957)\end{array}$ & $\begin{array}{c}0.0571 \\
(0.0732)\end{array}$ & $\begin{array}{c}0.0582 \\
(0.0723)\end{array}$ & $\begin{array}{c}0.0364 \\
(0.0743)\end{array}$ \\
\hline CSR* Tariff CUT & $\begin{array}{l}0.1209 * * \\
(0.0600)\end{array}$ & $\begin{array}{l}-0.0002 \\
(0.0011)\end{array}$ & $\begin{array}{l}-0.1136 \\
(0.0805)\end{array}$ & $\begin{array}{l}-0.1119 \\
(0.0797)\end{array}$ & $\begin{array}{l}-0.0561 \\
(0.0823)\end{array}$ \\
\hline Market-to-Book & $\begin{array}{l}-0.0032 * \\
(0.0018)\end{array}$ & $\begin{array}{c}0.0029 \\
(0.0026)\end{array}$ & $\begin{array}{c}0.0035 \\
(0.0026)\end{array}$ & $\begin{array}{c}0.0036 \\
(0.0026)\end{array}$ & $\begin{array}{c}0.0040 \\
(0.0028)\end{array}$ \\
\hline Leverage & $\begin{array}{c}-0.0780 * * * \\
(0.0206)\end{array}$ & $\begin{array}{l}0.0749 * \\
(0.0389)\end{array}$ & $\begin{array}{c}0.0806 * * \\
(0.0398)\end{array}$ & $\begin{array}{c}0.0811 * * \\
(0.0397)\end{array}$ & $\begin{array}{c}0.0616 \\
(0.0464)\end{array}$ \\
\hline Operating Margin & $\begin{array}{c}-0.0110 * * * \\
(0.0007)\end{array}$ & $\begin{array}{c}-0.0175 * * * \\
(0.0028)\end{array}$ & $\begin{array}{c}-0.0185^{* * * *} \\
(0.0028)\end{array}$ & $\begin{array}{c}-0.0182 * * * \\
(0.0028)\end{array}$ & $\begin{array}{c}-0.0176 * * * \\
(0.0029)\end{array}$ \\
\hline Investment & $\begin{array}{c}-0.0520 * * * \\
(0.0106)\end{array}$ & $\begin{array}{c}0.0455^{* *} \\
(0.0219)\end{array}$ & $\begin{array}{c}0.0596 * * * \\
(0.0221)\end{array}$ & $\begin{array}{c}0.0577 * * * \\
(0.0220)\end{array}$ & $\begin{array}{c}0.0607 * * \\
(0.0274)\end{array}$ \\
\hline Sales Growth & $\begin{array}{c}0.0002 \\
(0.0064)\end{array}$ & $\begin{array}{c}0.0194 \\
(0.0158)\end{array}$ & $\begin{array}{c}0.0242 \\
(0.0164)\end{array}$ & $\begin{array}{c}0.0229 \\
(0.0163)\end{array}$ & $\begin{array}{c}0.0242 \\
(0.0196)\end{array}$ \\
\hline Negative Equity & $\begin{array}{c}0.2602 * * * \\
(0.0192)\end{array}$ & $\begin{array}{c}0.1423 * * * \\
(0.0451)\end{array}$ & $\begin{array}{c}0.1445 * * * \\
(0.0453)\end{array}$ & $\begin{array}{c}0.1436 * * * \\
(0.0453)\end{array}$ & $\begin{array}{c}0.1411 * * * \\
(0.0518)\end{array}$ \\
\hline Constant & $\begin{array}{c}1.0123 * * * \\
(0.0108)\end{array}$ & $\begin{array}{c}0.8392 * * * \\
(0.0225)\end{array}$ & $\begin{array}{c}0.8525 * * * \\
(0.0232)\end{array}$ & $\begin{array}{c}0.8129 * * * \\
(0.0222)\end{array}$ & $\begin{array}{c}0.8020 * * * \\
(0.0275)\end{array}$ \\
\hline
\end{tabular}




\begin{tabular}{lccccc} 
Observations & 17,558 & 3,800 & 3,800 & 3,800 & 2,616 \\
Industry FE & YES & YES & YES & YES & YES \\
Year FE & YES & YES & YES & YES & YES \\
Adj R-squared & 0.365 & 0.465 & 0.445 & 0.447 & 0.464 \\
\hline
\end{tabular}

Panel B: Cash Flow Volatility

\begin{tabular}{|c|c|c|c|c|c|}
\hline & $\begin{array}{c}(1) \\
\text { CSR/No } \\
\text { CSR } \\
\end{array}$ & CSR Score & $\begin{array}{c}(3) \\
\text { High CSR } \\
\text { Score } \\
(\text { Mean) } \\
\end{array}$ & $\begin{array}{c}(4) \\
\text { High CSR } \\
\text { Score } \\
\text { (Median) }\end{array}$ & $\begin{array}{c}(5) \\
\text { High CSR } \\
\text { Score } \\
\text { (Tercile) } \\
\end{array}$ \\
\hline CSR & $-0.0181 * * *$ & $-0.0001 * *$ & -0.0039 & $-0.0052 * *$ & $-0.0062 *$ \\
\hline Tariff CUT & $\begin{array}{c}(0.0022) \\
-0.0053 \\
(0.0075)\end{array}$ & $\begin{array}{l}(0.0000) \\
-0.0076 \\
(0.0120)\end{array}$ & $\begin{array}{c}(0.0026) \\
0.0029 \\
(0.0068)\end{array}$ & $\begin{array}{c}(0.0026) \\
0.0024 \\
(0.0068)\end{array}$ & $\begin{array}{c}(0.0037) \\
0.0004 \\
(0.0084)\end{array}$ \\
\hline $\mathrm{CSR}^{*}$ Tariff CUT & $\begin{array}{l}-0.0055 \\
(0.0089)\end{array}$ & $\begin{array}{c}0.0000 \\
(0.0001)\end{array}$ & $\begin{array}{l}-0.0111 \\
(0.0103)\end{array}$ & $\begin{array}{l}-0.0104 \\
(0.0102)\end{array}$ & $\begin{array}{c}0.0015 \\
(0.0091)\end{array}$ \\
\hline Market-to-Book & $\begin{array}{c}0.0087 * * * \\
(0.0009)\end{array}$ & $\begin{array}{c}0.0075^{* * *} \\
(0.0014)\end{array}$ & $\begin{array}{c}0.0076^{* * * *} \\
(0.0014)\end{array}$ & $\begin{array}{c}0.0075^{* * * *} \\
(0.0014)\end{array}$ & $\begin{array}{c}0.0085^{* * * *} \\
(0.0016)\end{array}$ \\
\hline Leverage & $\begin{array}{c}-0.0293 * * * \\
(0.0084)\end{array}$ & $\begin{array}{c}0.0212 \\
(0.0167)\end{array}$ & $\begin{array}{c}0.0213 \\
(0.0167)\end{array}$ & $\begin{array}{c}0.0214 \\
(0.0167)\end{array}$ & $\begin{array}{c}0.0280 \\
(0.0194)\end{array}$ \\
\hline Profitability & $\begin{array}{c}-0.1925 * * * \\
(0.0060)\end{array}$ & $\begin{array}{c}-0.1781 * * * \\
(0.0230)\end{array}$ & $\begin{array}{c}-0.1799 * * * \\
(0.0227)\end{array}$ & $\begin{array}{c}-0.1793 * * * \\
(0.0228)\end{array}$ & $\begin{array}{c}-0.1874 * * * \\
(0.0276)\end{array}$ \\
\hline Cash & $\begin{array}{c}0.1123 * * * \\
(0.0098)\end{array}$ & $\begin{array}{c}0.1373 * * * \\
(0.0334)\end{array}$ & $\begin{array}{c}0.1388 * * * \\
(0.0336)\end{array}$ & $\begin{array}{c}0.1381 * * * \\
(0.0335)\end{array}$ & $\begin{array}{c}0.1509 * * * \\
(0.0414)\end{array}$ \\
\hline Investment & $\begin{array}{c}0.0006 \\
(0.0052)\end{array}$ & $\begin{array}{l}-0.0075 \\
(0.0126)\end{array}$ & $\begin{array}{l}-0.0062 \\
(0.0124)\end{array}$ & $\begin{array}{l}-0.0068 \\
(0.0124)\end{array}$ & $\begin{array}{c}-0.0071 \\
(0.0156)\end{array}$ \\
\hline Negative Equity & $\begin{array}{c}0.0375^{* * * *} \\
(0.0076)\end{array}$ & $\begin{array}{c}0.0368 * * \\
(0.0160)\end{array}$ & $\begin{array}{c}0.0368 * * \\
(0.0160)\end{array}$ & $\begin{array}{c}0.0368 * * \\
(0.0160)\end{array}$ & $\begin{array}{l}0.0398 * \\
(0.0208)\end{array}$ \\
\hline Constant & $\begin{array}{c}0.1004 * * * \\
(0.0038)\end{array}$ & $\begin{array}{c}0.1202 * * * \\
(0.0059)\end{array}$ & $\begin{array}{c}0.1178 * * * \\
(0.0056)\end{array}$ & $\begin{array}{c}0.1183 * * * \\
(0.0057)\end{array}$ & $\begin{array}{c}0.0922 * * * \\
(0.0058)\end{array}$ \\
\hline Observations & 17,151 & 3,699 & 3,699 & 3,697 & 2,549 \\
\hline Industry FE & YES & YES & YES & YES & YES \\
\hline Year FE & YES & YES & YES & YES & YES \\
\hline Adj R-squared & 0.492 & 0.401 & 0.400 & 0.400 & 0.428 \\
\hline
\end{tabular}




\section{Appendix A. Variable Definitions}

\begin{tabular}{|c|c|}
\hline Variables & Definitions \\
\hline CSR & Equally-weighted Overall ESG score from Asset4. \\
\hline Return Volatility & $\begin{array}{l}\text { The standard deviation of the firms' daily logarithmic returns (source: } \\
\text { CRSP), multiplied by the square root of the } 252 \text { total trading days } \\
\text { over a year. }\end{array}$ \\
\hline Cash flow & Operating Income before depreciation (Compustat item OIBDP). \\
\hline Cash Flow Volatility & $\begin{array}{l}\text { The standard deviation of cash flow (Compustat item OIBDP) scaled } \\
\text { by total assets (Compustat item AT) for the previous } 3 \text { years, } t-3 \text { to } t \text { - } \\
\text { 1. }\end{array}$ \\
\hline Election & $\begin{array}{l}\text { Binary variable, which is equal to one if a gubernatorial election } \\
\text { occurred in the firm's state of headquarters on time } t \text {, otherwise it } \\
\text { equals zero. }\end{array}$ \\
\hline Close Election & $\begin{array}{l}\text { Binary variable, which is equal to one if the victory margin of the } \\
\text { headquarter state's gubernatorial election at year } t \text { is at the lowest } \\
\text { quartile, otherwise it equals zero. }\end{array}$ \\
\hline Market to Book & $\begin{array}{l}\text { Market value of equity (Compustat item PRCC times item CSHO) } \\
\text { over total assets (Compustat item AT). }\end{array}$ \\
\hline Leverage & $\begin{array}{l}\text { Long-term debt (Compustat item DLTT) over total assets (Compustat } \\
\text { item AT). }\end{array}$ \\
\hline Operating margin & $\begin{array}{l}\text { Operating income before depreciation (Compustat item OIBDP) } \\
\text { scaled by sales (Compustat item SALE). }\end{array}$ \\
\hline Investment & $\begin{array}{l}\text { Percentage change in gross plant, property, and equipment } \\
\text { (Compustat item PPEGT) from year } \mathrm{t}-1 \text { to year } \mathrm{t} \text {. }\end{array}$ \\
\hline
\end{tabular}




\begin{tabular}{|l|l|}
\hline Sales growth & Growth in sales from year t-1 to year t (Compustat item SALE). \\
\hline Profitability & The ratio of net income before extraordinary items (Compustat item \\
\hline Cash & $\begin{array}{l}\text { Cash (Compustat item CH) scaled by total assets (Compustat item } \\
\text { AT). }\end{array}$ \\
\hline Negative Equity & $\begin{array}{l}\text { Equal to } 1 \text { if the book value of equity (Compustat item CEQ) over } \\
\text { market value of equity (Compustat item PRCC times item CSHO) is } \\
\text { negative, otherwise 0. }\end{array}$ \\
\hline Term Limit & $\begin{array}{l}\text { Equal to 1 if the incumbent governor has term limit on gubernatorial } \\
\text { election, otherwise } 0 .\end{array}$ \\
\hline A GDP & Annual percentage change in state GDP. \\
\hline Unemployment & Annual state-level unemployment rate. \\
\hline
\end{tabular}


Table A1. The relationship between CSR reputation and risk during Political Uncertainty

This table presents the results of instrumental variable (IV) approach, which estimates the relationship between CSR reputation and risk during political uncertainty over the sample period of 2002-2016. As risk measure, we use stock return volatility as dependent variable. Stock return volatility is the standard deviation of the firms' daily logarithmic returns, multiplied by the square root of 252 trading days. CSR is the overall ESG score instrumented with two instruments separately: the average CSR rating for each industry-year pair (Panel A) and state-year pair (Panel B). The results of $1^{\text {st }}$ stage are presented in column 1. Column 2, 4 and 6 contains results of $2^{\text {nd }}$ stage regression without control variables. In columns 3,5 and 7, we report the $2^{\text {nd }}$ stage regression outcomes with control variables. To measure political uncertainty, we use two binary variables: (i) Election, a binary variable equal to one if a gubernatorial election occurred in the firm's state of headquarters on time $t$, and zero otherwise; (ii) Close, a binary variable equal to one if the vote margin between top two candidates remains in the lowest quartile, and zero otherwise. Postelection is a binary variable equal to one if a gubernatorial election occurred in the firm's state of headquarters lagged by a year $(t-1)$. Values of risk and CSR measures are contemporaneous. All firm-level financial controls, state-level GDP growth rate, and unemployment rate are lagged by one year. All variables are defined in the Appendix. All regressions include industry and year fixed effects. We use heteroscedasticity robust standard errors clustered at the firm level, which are reported in parentheses. ***, **, and * indicate significance at $1 \%, 5 \%$, and $10 \%$ level, respectively. All continuous variables are winsorized at the $1 \%$ and $99 \%$ tails.

\section{Panel A: Stock return volatility - Industry Average CSR as Instruments}

(1)

Ind_CSR10 $0.2005 * * *$ $(0.0375)$

CSR

Election

CSR*Election

Close Election

CSR* Close Election

Post-election
(2)

(3)

$\begin{array}{cc}-0.0057 * * * & -0.0047 * * * \\ (0.0010) & (0.0010) \\ 0.0285 * * * & 0.0312 * * * \\ (0.0066) & (0.0065) \\ -0.0019 * * * & -0.0017 * * * \\ (0.0004) & (0.0004)\end{array}$

(4)

$-0.0060 * * *$

(0.0011)

(0.0011)

$(0.0010)$

$-0.0062 * * *$

(0.0011)

$-0.0051 * * *$

(0.0011)

(7)

$\begin{array}{cc}0.0554 * * * & 0.0578 * * * \\ (0.0122) & (0.0118) \\ -0.0030 * * * & -0.0030 * * * \\ (0.0009) & (0.0009)\end{array}$

$(0.0009) \quad(0.0009)$

0.0065

0.0052 
CSR* Post-election

$\begin{array}{lc}\text { Market-to-Book } & 1.0572 * * * \\ & (0.1616) \\ \text { Leverage } & 13.9689^{* * *} \\ & (1.5005) \\ \text { Operating Margin } & 0.6288^{* * *} \\ & (0.0517) \\ \text { Investment } & -3.4353^{* * *} \\ & (0.5066) \\ \text { Sales Growth } & -2.5655^{* * *} \\ & (0.2810) \\ \text { Negative Equity } & -8.9496^{* * *} \\ & (0.9891) \\ \text { Term Limit } & -0.9462 * \\ & (0.5627) \\ \Delta \text { GDP } & -12.4487 \\ & (8.2756) \\ \text { Unemployment } & 0.5951 * * \\ & (0.3022) \\ \text { Constant } & -2.6576 \\ & (10.8940)\end{array}$

\begin{tabular}{|c|c|c|c|c|}
\hline & & & $\begin{array}{c}(0.0057) \\
0.0002 \\
(0.0003)\end{array}$ & $\begin{array}{c}(0.0056) \\
0.0002 \\
(0.0003)\end{array}$ \\
\hline $\begin{array}{c}-0.0074 * * * \\
(0.0018)\end{array}$ & & $\begin{array}{c}-0.0075 * * * \\
(0.0017)\end{array}$ & & $\begin{array}{c}-0.0075 * * * \\
(0.0017)\end{array}$ \\
\hline $\begin{array}{c}-0.0652 * * * \\
(0.0202)\end{array}$ & & $\begin{array}{c}-0.0640 * * * \\
(0.0202)\end{array}$ & & $\begin{array}{c}-0.0658 * * * \\
(0.0201)\end{array}$ \\
\hline $\begin{array}{c}-0.0118 * * * \\
(0.0009)\end{array}$ & & $\begin{array}{c}-0.0118 * * * \\
(0.0009)\end{array}$ & & $\begin{array}{c}-0.0118 * * * \\
(0.0009)\end{array}$ \\
\hline$-0.0606 * * *$ & & $-0.0608 * * *$ & & $-0.0605^{* * *} *$ \\
\hline$(0.0084)$ & & $(0.0084)$ & & $(0.0084)$ \\
\hline-0.0052 & & -0.0050 & & -0.0053 \\
\hline$(0.0061)$ & & $(0.0061)$ & & $(0.0061)$ \\
\hline $0.2396 * * *$ & & $0.2394 * * *$ & & $0.2400 * * *$ \\
\hline$(0.0163)$ & & $(0.0163)$ & & $(0.0163)$ \\
\hline$-0.0272 * * *$ & & $-0.0305 * * *$ & & $-0.0224 * * *$ \\
\hline$(0.0068)$ & & $(0.0064)$ & & $(0.0062)$ \\
\hline 0.0251 & & 0.0936 & & 0.0236 \\
\hline$(0.0790)$ & & $(0.0791)$ & & $(0.0790)$ \\
\hline $\begin{array}{c}0.0079 * * * \\
(0.0021)\end{array}$ & & $\begin{array}{c}0.0083 * * * \\
(0.0021)\end{array}$ & & $\begin{array}{c}0.0079 * * * \\
(0.0021)\end{array}$ \\
\hline $\begin{array}{c}0.6179 * * * \\
(0.0557)\end{array}$ & $\begin{array}{c}0.6381 * * * \\
(0.0636)\end{array}$ & $\begin{array}{c}0.6151 * * * \\
(0.0552)\end{array}$ & $\begin{array}{c}0.6586^{* * * *} \\
(0.0636)\end{array}$ & $\begin{array}{c}0.6401 * * * \\
(0.0547)\end{array}$ \\
\hline 43,631 & 43,631 & 43,631 & 43,631 & 43,631 \\
\hline YES & YES & YES & YES & YES \\
\hline YES & YES & YES & YES & YES \\
\hline 187.9 & 214.6 & 189.2 & 214.2 & 188.9 \\
\hline
\end{tabular}


Panel B: Stock return volatility - State Average CSR as Instruments

\begin{tabular}{|c|c|c|c|c|c|c|c|}
\hline & (1) & (2) & (3) & (4) & (5) & (6) & (7) \\
\hline State Average CSR & $\begin{array}{c}0.3115^{* * * *} \\
(0.0934)\end{array}$ & & & & & & \\
\hline CSR & & $\begin{array}{c}-0.0108 * * * \\
(0.0027)\end{array}$ & $\begin{array}{c}-0.0124 * * * \\
(0.0034)\end{array}$ & $\begin{array}{c}-0.0113 * * * \\
(0.0027)\end{array}$ & $\begin{array}{c}-0.0127 * * * \\
(0.0035)\end{array}$ & $\begin{array}{c}-0.0114 * * * \\
(0.0028)\end{array}$ & $\begin{array}{c}-0.0130 * * * \\
(0.0036)\end{array}$ \\
\hline Election & & $\begin{array}{c}0.0391 * * * \\
(0.0098)\end{array}$ & $\begin{array}{c}0.0419 * * * \\
(0.0100)\end{array}$ & & & & \\
\hline CSR*Election & & $\begin{array}{c}-0.0031 \text { *** } \\
(0.0008)\end{array}$ & $\begin{array}{c}-0.0029 * * * \\
(0.0008)\end{array}$ & & & & \\
\hline Close Election & & & & $\begin{array}{c}0.0614 * * * \\
(0.0147)\end{array}$ & $\begin{array}{c}0.0727 * * * \\
(0.0160)\end{array}$ & & \\
\hline CSR $*$ Close Election & & & & $\begin{array}{c}-0.0034 * * * \\
(0.0012)\end{array}$ & $\begin{array}{c}-0.0040 * * * \\
(0.0013)\end{array}$ & & \\
\hline Post-election & & & & & & $\begin{array}{l}0.0161 * \\
(0.0092)\end{array}$ & $\begin{array}{c}0.0102 \\
(0.0095)\end{array}$ \\
\hline CSR* Post-election & & & & & & $\begin{array}{l}-0.0008 \\
(0.0007)\end{array}$ & $\begin{array}{l}-0.0004 \\
(0.0007)\end{array}$ \\
\hline Market-to-Book & $\begin{array}{c}1.0608 * * * \\
(0.1622)\end{array}$ & & $\begin{array}{c}0.0009 \\
(0.0042)\end{array}$ & & $\begin{array}{c}0.0006 \\
(0.0042)\end{array}$ & & $\begin{array}{c}0.0009 \\
(0.0042)\end{array}$ \\
\hline Leverage & $\begin{array}{c}13.9855^{* * *} \\
(1.5055)\end{array}$ & & $\begin{array}{c}0.0487 \\
(0.0533)\end{array}$ & & $\begin{array}{c}0.0486 \\
(0.0530)\end{array}$ & & $\begin{array}{c}0.0492 \\
(0.0537)\end{array}$ \\
\hline Operating Margin & $\begin{array}{c}0.6566 * * * \\
(0.0517)\end{array}$ & & $\begin{array}{c}-0.0065^{* * *} \\
(0.0024)\end{array}$ & & $\begin{array}{c}-0.0065^{* * *} * \\
(0.0024)\end{array}$ & & $\begin{array}{c}-0.0065^{* * * *} \\
(0.0024)\end{array}$ \\
\hline Investment & $\begin{array}{c}-3.2932 * * * \\
(0.5056)\end{array}$ & & $\begin{array}{c}-0.0880 * * * \\
(0.0144)\end{array}$ & & $\begin{array}{c}-0.0880 * * * \\
(0.0144)\end{array}$ & & $\begin{array}{c}-0.0883 * * * \\
(0.0145)\end{array}$ \\
\hline Sales Growth & $-2.5973 * * *$ & & $-0.0261 * *$ & & $-0.0254 * *$ & & $-0.0263 * *$ \\
\hline
\end{tabular}




\begin{tabular}{|c|c|c|c|c|c|c|c|}
\hline & $(0.2821)$ & & $(0.0107)$ & & $(0.0106)$ & & $(0.0107)$ \\
\hline \multirow[t]{2}{*}{ Negative Equity } & $-8.9727 * * *$ & & $0.1668 * * *$ & & $0.1677 * * *$ & & $0.1666 * * *$ \\
\hline & (1.0058) & & $(0.0355)$ & & $(0.0353)$ & & $(0.0358)$ \\
\hline \multirow[t]{2}{*}{ Term Limit } & -0.7097 & & $-0.0333 * * *$ & & $-0.0397 * * *$ & & $-0.0302 * * *$ \\
\hline & $(0.5567)$ & & $(0.0099)$ & & $(0.0092)$ & & $(0.0085)$ \\
\hline \multirow[t]{2}{*}{$\Delta \mathrm{GDP}$} & -7.2600 & & -0.0696 & & 0.0177 & & -0.0697 \\
\hline & $(8.0259)$ & & $(0.1108)$ & & $(0.1108)$ & & $(0.1121)$ \\
\hline \multirow[t]{2}{*}{ Unemployment } & 0.4657 & & $0.0128 * * *$ & & $0.0133 * * *$ & & $0.0129 * * *$ \\
\hline & $(0.3033)$ & & $(0.0041)$ & & $(0.0040)$ & & $(0.0041)$ \\
\hline \multirow[t]{2}{*}{ Constant } & -1.8916 & $0.6544 * * *$ & $0.5956 * * *$ & $0.6578 * * *$ & $0.5932 * * *$ & $0.6795 * * *$ & $0.6233 * * *$ \\
\hline & $(10.3355)$ & $(0.1154)$ & $(0.1343)$ & $(0.1128)$ & $(0.1313)$ & $(0.1136)$ & $(0.1328)$ \\
\hline Observations & 43,631 & 43,631 & 43,631 & 43,631 & 43,631 & 43,631 & 43,631 \\
\hline Industry FE & YES & YES & YES & YES & YES & YES & YES \\
\hline Year FE & YES & YES & YES & YES & YES & YES & YES \\
\hline Cragg-Donald Wald & & 80.38 & 59.46 & 79.22 & 58.76 & 79.66 & 58.66 \\
\hline
\end{tabular}


Table A2. The relationship between CSR reputation and risk during Political Uncertainty

This table presents the results of instrumental variable (IV) approach, which estimates the relationship between CSR reputation and risk during political uncertainty over the sample period of 2002-2016. As risk measure, we use cash flow volatility as dependent variable. Cash flow volatility, which is standard deviation of cash flow to assets for the previous three years. CSR is the overall ESG score instrumented with two instruments separately: the average CSR rating for each industry-year pair (Panel A) and state-year pair (Panel B). The results of $1^{\text {st }}$ stage are presented in column 1. Column 2, 4 and 6 contains results of $2^{\text {nd }}$ stage regression without control variables. In columns 3,5 and 7 , we report the $2^{\text {nd }}$ stage regression outcomes with control variables. To measure political uncertainty, we use two binary variables: (i) Election, a binary variable equal to one if a gubernatorial election occurred in the firm's state of headquarters on time $t$, and zero otherwise; (ii) Close, a binary variable equal to one if the vote margin between top two candidates remains in the lowest quartile, and zero otherwise. Post-election is a binary variable equal to one if a gubernatorial election occurred in the firm's state of headquarters lagged by a year $(t-1)$. Values of risk and CSR measures are contemporaneous. All firm-level financial controls, state-level GDP growth rate, and unemployment rate are lagged by one year. All variables are defined in the Appendix. All regressions include industry and year fixed effects. We use heteroscedasticity robust standard errors clustered at the firm level, which are reported in parentheses. $* * *, * *$, and $*$ indicate significance at $1 \%, 5 \%$, and $10 \%$ level, respectively. All continuous variables are winsorized at the $1 \%$ and $99 \%$ tails.

\section{Panel A: Cash Flow Volatility - Industry Average CSR as Instrument}

$(1)$

$(2)$

(3)

(4)

(5)

(6)

(7)

Industry Average CSR

CSR

Election

CSR*Election

Close Election

\section{$0.1830 * * *$}

(0.0359)

$\begin{array}{cc}-0.0028 * * * & -0.0010 * * * \\ (0.0005) & (0.0003) \\ 0.0087 * * * & 0.0021 \\ (0.0024) & (0.0020) \\ -0.0005 * * * & -0.0000 \\ (0.0002) & (0.0001)\end{array}$


CSR* Close Election

Post-election

CSR* Post-election

Market-to-Book

Leverage

Profitability

Cash

Investment

Negative Equity

Term Limit

$\triangle$ GDP

Unemployment

Constant

Observations

\section{$-0.0006$ \\ 0.0000 \\ (0.0003) \\ (0.0002)}

$0.0115 * * *$
$(0.0008)$
$-0.0109 * *$
$(0.0055)$
$-0.1655^{* * *}$
$(0.0060)$
$0.0959 * * *$
$(0.0079)$
0.0024
$(0.0037)$
$0.0266 * * *$
$(0.0042)$
-0.0030
$(0.0021)$
$-0.0507 * *$
$(0.0256)$
0.0004
$(0.0007)$
$0.0199 *$
$(0.0112)$

$0.0115^{* * * *}$ (0.0008) $-0.0110^{* *}$ (0.0055)

$-0.1655^{* * * *}$ (0.0060) $0.0959 * * *$ (0.0079) 0.0024 (0.0037) $0.0267 * * *$ (0.0042) $-0.0028$ (0.0020) $-0.0463 *$ (0.0257) 0.0004 (0.0007) $0.0203 *$ (0.0112)

$\begin{array}{cc}0.0028 & 0.0004 \\ (0.0024) & (0.0019) \\ -0.0000 & 0.0000 \\ (0.0001) & (0.0001) \\ & 0.0115^{* * *} \\ & (0.0008) \\ & -0.0109 * * \\ & (0.0055) \\ & -0.1655^{* * *} \\ & (0.0060) \\ & 0.0959^{* * *} \\ & (0.0079) \\ & 0.0024 \\ & (0.0037) \\ & 0.0266^{* * *} \\ & (0.0042) \\ & -0.0023 \\ & (0.0019) \\ & -0.0511^{* *} \\ & (0.0256) \\ 0.0565^{*} & 0.0004 \\ (0.0307) & (0.0007) \\ & 0.0216^{*} \\ & (0.0111)\end{array}$

$0.0505^{*}$

(0.0310)

41,903

41,903

41,903

41,903

41,903 


\begin{tabular}{|c|c|c|c|c|c|c|c|}
\hline Industry FE & YES & YES & YES & YES & YES & YES & YES \\
\hline Year FE & YES & YES & YES & YES & YES & YES & YES \\
\hline
\end{tabular}

Panel B: Cash Flow Volatility - State Average CSR as Instrument

\begin{tabular}{|c|c|c|c|c|c|c|c|}
\hline & $(1)$ & $(2)$ & (3) & (4) & (5) & $(6)$ & (7) \\
\hline State Average CSR & $\begin{array}{c}0.2369 * * * \\
(0.0917)\end{array}$ & & & & & & \\
\hline Election & & $\begin{array}{c}0.0130 * * * \\
(0.0036)\end{array}$ & $\begin{array}{c}0.0036 \\
(0.0029)\end{array}$ & & & & \\
\hline Close Election & & & & $\begin{array}{c}0.0174 * * * \\
(0.0051)\end{array}$ & $\begin{array}{c}0.0037 \\
(0.0039)\end{array}$ & & \\
\hline CSR $*$ Close Election & & & & $\begin{array}{l}-0.0007 \\
(0.0004)\end{array}$ & $\begin{array}{l}-0.0000 \\
(0.0003)\end{array}$ & & \\
\hline Post-election & & & & & & $\begin{array}{c}0.0081 * * \\
(0.0038)\end{array}$ & $\begin{array}{c}0.0037 \\
(0.0030)\end{array}$ \\
\hline Market-to-Book & $\begin{array}{c}1.5842 * * * \\
(0.1628)\end{array}$ & & $\begin{array}{c}0.0118 * * * \\
(0.0013)\end{array}$ & & $\begin{array}{c}0.0119 * * * \\
(0.0013)\end{array}$ & & $\begin{array}{c}0.0118 * * * \\
(0.0013)\end{array}$ \\
\hline Leverage & $\begin{array}{c}11.8606 * * * \\
(1.5489)\end{array}$ & & $\begin{array}{l}-0.0081 \\
(0.0095)\end{array}$ & & $\begin{array}{l}-0.0077 \\
(0.0096)\end{array}$ & & $\begin{array}{l}-0.0083 \\
(0.0095)\end{array}$ \\
\hline
\end{tabular}




\begin{tabular}{|c|c|c|c|c|c|c|c|}
\hline Profitability & $\begin{array}{c}14.2469 * * * \\
(0.8162)\end{array}$ & & $\begin{array}{c}-0.1620^{* * * *} \\
(0.0112)\end{array}$ & & $\begin{array}{c}-0.1616^{* * * *} \\
(0.0113)\end{array}$ & & $\begin{array}{c}-0.1623 * * * \\
(0.0112)\end{array}$ \\
\hline Negative Equity & $\begin{array}{c}-5.1712 * * * \\
(0.9778)\end{array}$ & & $\begin{array}{c}0.0254 * * * \\
(0.0055)\end{array}$ & & $\begin{array}{c}0.0253 * * * \\
(0.0055)\end{array}$ & & $\begin{array}{c}0.0255^{* * *} \\
(0.0055)\end{array}$ \\
\hline$\Delta \mathrm{GDP}$ & $\begin{array}{l}-7.8737 \\
(8.0237)\end{array}$ & & $\begin{array}{c}-0.0535^{* *} \\
(0.0269)\end{array}$ & & $\begin{array}{l}-0.0485^{*} \\
(0.0271)\end{array}$ & & $\begin{array}{c}-0.0539 * * \\
(0.0268)\end{array}$ \\
\hline Unemployment & $\begin{array}{c}0.7465^{* *} \\
(0.3027)\end{array}$ & & $\begin{array}{c}0.0006 \\
(0.0009)\end{array}$ & & $\begin{array}{c}0.0007 \\
(0.0009)\end{array}$ & & $\begin{array}{c}0.0006 \\
(0.0009)\end{array}$ \\
\hline Constant & $\begin{array}{c}-1.7198 \\
(10.4491)\end{array}$ & $\begin{array}{c}0.0504 \\
(0.0378)\end{array}$ & $\begin{array}{c}0.0186 \\
(0.0137)\end{array}$ & $\begin{array}{c}0.0530 \\
(0.0374)\end{array}$ & $\begin{array}{c}0.0194 \\
(0.0137)\end{array}$ & $\begin{array}{c}0.0586 \\
(0.0371)\end{array}$ & $\begin{array}{c}0.0209 \\
(0.0132)\end{array}$ \\
\hline Industry FE & YES & YES & YES & YES & YES & YES & YES \\
\hline Year FE & YES & YES & YES & YES & YES & YES & YES \\
\hline Cragg-Donald Wald & & 76.04 & 34.87 & 74.32 & 34.20 & 75.69 & 34.52 \\
\hline
\end{tabular}

